\title{
Alzheimer's Therapeutics: Translation of Preclinical Science to Clinical Drug Development
}

\author{
Alena V Savonenko*,1,2, Tatiana Melnikova ${ }^{1}$, Andrew Hiatt ${ }^{3}$, Tong Li ${ }^{1}$, Paul F Worley ${ }^{4}$, Juan C Troncoso ${ }^{1}$, \\ Phil C Wong ${ }^{1,4}$ and Don L Price ${ }^{1,2,4}$ \\ ${ }^{1}$ Department of Pathology, Johns Hopkins University School of Medicine, Baltimore, MD, USA; ${ }^{2}$ Department of Neurology, \\ Johns Hopkins University School of Medicine, Baltimore, MD, USA; ${ }^{3}$ MAPP Biopharmaceutical, San Diego, CA, USA; \\ ${ }^{4}$ Department of Neuroscience, Johns Hopkins University School of Medicine, Baltimore, MD, USA
}

Over the past three decades, significant progress has been made in understanding the neurobiology of Alzheimer's disease. In recent years, the first attempts to implement novel mechanism-based treatments brought rather disappointing results, with low, if any, drug efficacy and significant side effects. A discrepancy between our expectations based on preclinical models and the results of clinical trials calls for a revision of our theoretical views and questions every stage of translation - from how we model the disease to how we run clinical trials. In the following sections, we will use some specific examples of the therapeutics from acetylcholinesterase inhibitors to recent anti-A $\beta$ immunization and $\gamma$-secretase inhibition to discuss whether preclinical studies could predict the limitations in efficacy and side effects that we were so disappointed to observe in recent clinical trials. We discuss ways to improve both the predictive validity of mouse models and the translation of knowledge between preclinical and clinical stages of drug development.

Neuropsychopharmacology Reviews (2012) 37, 261-277; doi: I0.1038/npp.201 I.21 I; published online 21 September 201 I

Keywords: animal models; neurodegeneration; $\gamma$-secretase inhibition; amyloid cascade; anti- $\beta$ immunization; acetylcholinesterase inhibitors

\section{INTRODUCTION}

Alzheimer's disease (AD), which affects more than 4 million individuals in the United States, is characterized by progressive deficits in memory and cognitive and behavioral impairments that ultimately lead to dementia (Cummings, 2004; Wong and Price, 2005). Prevalence, cost of care, impact on individuals and caregivers, and lack of mechanism-based treatments make $\mathrm{AD}$ one of the most challenging diseases. The syndrome of $\mathrm{AD}$ results from dysfunction and death of neurons in specific regions/ circuits, particularly those populations of nerve cells subserving memory and cognition (Braak and Braak, 1991; Whitehouse et al, 1982; for review see Wong and Price, 2005). Characteristics of the neuropathology are accumulations of intracellular and extracellular protein aggregates. Abnormally phosphorylated tau assembles into paired helical filaments that aggregate into neurofibrillary

${ }^{*}$ Correspondence: Dr AV Savonenko, Department of Pathology, Johns Hopkins University School of Medicine, Baltimore, MD 21205, USA. Tel: +1410 5025859 , Fax: +1 410955 9777, E-mail: asavone1@jhmi.edu Received 22 March 2011; revised 16 August 2011; accepted 16 August 2011 tangles (NFTs) in the neuronal perikarya and contribute to dystrophic neurites (Lee et al, 2001). The other pathological hallmark is the extracellular deposition of $\beta$-pleated assemblies of $\mathrm{A} \beta$ peptide forming diffuse and neuritic senile plaques (Braak and Braak, 1991).

Neurochemical examination of brain samples from $A D$ patients led to demonstration of a dramatic loss of cortical cholinergic innervations, and subsequent neuropathological studies revealed basal forebrain magnocellular neurons and cholinergic deficits in the cortex and hippocampus (Bartus et al, 1982; Coyle et al, 1983). Over the years, this discovery led to the introduction of cholinesterase inhibitors as a first treatment for AD. Later, evidence of involvement of glutamatergic systems in hippocampal and cortical circuits in $\mathrm{AD}$, coupled with information about glutamate excitotoxicity (mediated, in part, by NMDA-R), led to a second FDA-approved line of therapy, NMDA-R antagonists (Lipton, 2005). Both of these therapeutic strategies are associated with modest and transient symptomatic benefits in some patients (Lanctot et al, 2003b; Reisberg et al, 2003; Birks, 2006).

Observations of autosomal dominant inheritance of the disease in families with early-onset $\mathrm{AD}$ (fAD) in concert 
with the work of geneticists resulted in discoveries of mutations in genes encoding the amyloid precursor protein (APP) or the presenilins (PS1 and 2; for review see Price et al, 1998). Although the exact mechanisms affected by each mutation are quite different, the general outcome of $\mathrm{fAD}$-associated mutations is an increase in production of $\mathrm{A} \beta_{1-40}$ and/or $\mathrm{A} \beta_{1-42}$ peptides. More recently, the presence of alleles of other genes such as $A p o E$ has been shown to be significant risk factors for late-onset disease (Bertram and Tanzi, 2009; Kim et al, 2011). Although still preliminary, the mechanisms affected by the risk factors associated with late-onset $\mathrm{AD}$ are likely to include alterations in $\mathrm{A} \beta$ metabolism, $\mathrm{A} \beta$ aggregation/clearance, and/or cholesterol homeostasis (DeMattos et al, 2004).

Intensive studies in mechanisms of generation of $\mathrm{A} \beta$ peptides resulted in the discovery of sequential endoproteolytic cleavages of APP by two membrane-bound enzyme activities, termed $\beta$-site APP-cleaving enzyme 1 (BACE1) and $\gamma$-secretase. By using mouse models with genetically altered activities of BACE1 and/or $\gamma$-secretase, both of these enzymes have been experimentally validated as highpriority therapeutic targets for AD therapy (for review see Henley et al, 2009; Vassar et al, 2009). On the basis of preclinical studies, pharmacological inhibition of these activities has been predicted to decrease the generation of $\mathrm{A} \beta$ and to ameliorate cognitive decline in AD. However, when these novel mechanism-based experimental therapies were moved into clinical trials, researchers and clinicians faced numerous disappointments from lower, than expected, efficacy of treatments in ameliorating functional deficits, compounded by significant side effects. Such obvious discrepancies between outcomes of preclinical and clinical trials force us to re-evaluate our views on the disease, its models, and ways to resolve this translational dilemma (Golde et al, 2011).

\section{MODELING A $\beta$ AMYLOIDOSIS AND TAU PATHOLOGIES}

Early discoveries of mutations in APP and presenilins (PS1 and 2) in cases of FAD (Citron et al, 1992; Hardy, 1996; Sherrington et al, 1995) set the stage to create multiple transgenic mouse models of $\mathrm{A} \beta$ amyloidosis using a variety of strategies (for review see Jankowsky et al, 2002; Savonenko et al, 2005a; McGowan et al, 2006; Eriksen and Janus, 2007). These animal models range from mice transgenic for a single gene to more complex double and triple transgenic animals, which reproduce important features of $\mathrm{AD}$ including elevated levels of $\mathrm{A} \beta$ (particularly more amyloidogenic A $\beta 1-42$ peptide); amyloid plaques; reductions in neurotransmitter markers; age-related cognitive impairments; tau-immunoreactive NFT (less commonly in case of double or triple transgene); and death of some neuronal populations. There is remarkable consistency among different APP transgenic mice in terms of the agedependent cellular abnormalities characteristic of $\mathrm{AD}$, ie,
A $\beta$ amyloid deposits, neuritic plaques, and glial responses (for review see Price et al, 2007). These histopathological profiles have been identified in mice that express different isoforms of mutant human APP and with several different transgene constructs. A key factor is that the production of $\mathrm{A} \beta$ peptide is elevated sufficiently to induce plaque-related pathology.

Despite the success of transgenic approaches in mimicking Alzheimer-type cerebral amyloidosis, the modeling of another cardinal feature of $\mathrm{AD}$, ie, tau-related pathologies, was more complicated. Originally, researchers expected that robust deposition of $\mathrm{A} \beta$ amyloid in mouse models would also result in development of intracellular tau aggregates analogous to NFT and neuropil threads. However, tau pathology observed in APP transgenic models was scarce and mainly represented by increased tau phosphorylation. It has been suggested that the paucity of tau abnormalities in various lines of mutant mice with $\mathrm{A} \beta$ amyloidosis may be related to differences in tau isoforms expressed in these species as compared with humans. To model tau pathology in mice, researchers used genetic approaches to overexpress human wild-type (WT) or mutated tau (McGowan et al, 2006). For example, transgenic mice expressing tau P3O1L $_{\mathrm{P}}$ (a mutation linked to autosomal dominant frontotemporal dementia with Parkinsonism, FTDP) form abnormal neuronal tau-containing filaments that have striking similarities with the NFTs found in human cases of AD or FTDP (Lewis et al, 2001; Gotz et al, 2001). The tau filaments in the brains of transgenic mice are considerably less numerous than in the brains of $\mathrm{AD}$; however, an injection of A $\beta 42$ fibrils into the brains of $\operatorname{tau}_{P 301 L}$ mice dramatically increases the number of tangles in neurons projecting to the sites of $\mathrm{A} \beta$ injection (Gotz et al, 2001). Interactions between $\mathrm{A} \beta$ - and tau-related pathologies were also demonstrated in mice that coexpress APPswe and tau $\mathrm{P}_{\mathrm{P} 301 \mathrm{~L}}$ and exhibit enhanced tangle-like pathology in limbic system and olfactory cortex (Lewis et al, 2001). These observations are consistent with the hypothesis that $\mathrm{A} \beta$, if present in proximity to axon terminals, is able to facilitate the formation of tangles in neuronal cell bodies. Further attempts to create a mouse model that combines amyloidosis and tau pathology led to a triple transgenic mouse $(3 \times \mathrm{Tg}-\mathrm{AD})$ made by microinjecting APPswe and tau P $301 L$ into single cells derived from monozygous $P S 1_{M 146 V}$ knockin mice (Oddo et al, 2003). These mice develop age-related plaques and tangles and, alongside other models (Roberson et al, 2007), have been a valuable tool to investigate functional outcomes of $\mathrm{A} \beta$ and tau pathology.

It is important to note that no transgenic/mutant mouse model can provide an all encompassing view of the biology of a human disease (McArthur and Borsini, 2008), and particularly a disease involving changes in cognitive capacities like AD. Only a consensus about the most common and reproducible features from different $\mathrm{AD}$ models can ensure appropriate translation of preclinical findings into realistic expectations for efficacy of experimental therapies in clinic (Savonenko and Borchelt, 2008). 


\section{AMYLOID CASCADE HYPOTHESIS REVISITED}

Utilization of transgenic models of $\mathrm{AD}$ in the last decade significantly furthered our understanding of the pathogenesis of disease. The original amyloid cascade hypothesis proposed that the cause of neurodegeneration in $\mathrm{AD}$ is deposition of $\mathrm{A} \beta$ into plaques, a process that represents an initial early insult, leading to a series of downstream events ranging from inflammation to synapse loss to the triggering of tau hyperphosphorylation and finally to the death of susceptible neurons (Hardy and Higgins, 1992). Strong correlations between $\mathrm{A} \beta$ plaque levels and cognitive deficits have been reported in different mouse models of amyloidosis (Arendash et al, 2001; Chen et al, 2000; Gordon et al, 2001; Janus et al, 2000) supporting the causative role of $\mathrm{A} \beta$ plaques in memory decline. A lack of significant correlations between plaque load and dementia in $\mathrm{AD}$ patients (Giannakopoulos et al, 2003; Naslund et al, 2000) was somewhat disturbing, but could be explained by the notion that $\mathrm{A} \beta$ plaques starting to accumulate at the early stages of disease could bear less predictive power for dementia scores than events occurring much later in the cascade of pathologies such as accumulation of NFT. The notion of the critical role of $\mathrm{A} \beta$ plaques in cognitive decline survived a more stringent test for causality when a newly discovered anti-A $\beta$ active immunization approach was used in APP transgenic models, leading to amelioration of $\mathrm{A} \beta$ deposits (Schenk et al, 1999) and rescue of memory deficits (Janus et al, 2000; Morgan et al, 2000). However, further developments of the immunization approach demonstrated that cognitive deficits in mouse models of amyloidosis can be acutely rescued by systemic treatment with anti-A $\beta$ antibodies, without significant changes in levels of amyloid plaques (Dodart et al, 2002; Kotilinek et al, 2002). These findings pressed to revisit the amyloid cascade hypothesis to suggest that total amounts of $\mathrm{A} \beta$ accumulated during aging in the form of plaques may be only a surrogate marker for small 'non-plaque' $\mathrm{A} \beta$ assemblies that have a primary role in memory impairment (Westerman et al, 2002). The amyloid hypothesis was revised to include multiple $\mathrm{A} \beta$ assemblies as possible toxic entities: fibrils, protofibrils, dimers, trimers, dodecamers, and broadly defined $\mathrm{A} \beta$-derived diffusible ligands (for review see Caughey and Lansbury, 2003; Selkoe and Schenk, 2003). Considerable debate still exists concerning which of the $\mathrm{A} \beta$ species/conformational states is the principle toxic entity; however, it is likely that multiple $\mathrm{A} \beta$ species/assemblies are tidily balanced and represent a spectrum of toxicities dominated by various $\mathrm{A} \beta$ assemblies at different stages of disease (Savonenko et al, 2005a; Savonenko et al, 2005b; Lesne et al, 2008).

Developments in our understanding of tau-related mechanisms in $\mathrm{AD}$ have many analogies to the amyloid story. An original notion that NFT are the principal offenders mediating neuronal death and cognitive deficits has been revised to view NFTs, such as amyloid plaques, as the final pathological 'tombstones' rather than main neurotoxic agents. Neurotoxicity has recently been attributed to tau species that are intermediate between normally phosphorylated tau and the hyper-phosphorylated fibrils (Brunden et al, 2008; Jaworski et al, 2010). As in mice modeling $\mathrm{A} \beta$ amyloidosis, a dissociation between cognitive recovery and continuous presence of aggregates (in this case NTF) has been demonstrated in mice that conditionally overexpress mutated tau (Tet-off:Tau ${ }_{P 301}$ mice; Santacruz et al, 2005). The same study demonstrated that in addition to amelioration of cognitive deficits, the inhibition of $\mathrm{Tau}_{\mathrm{P} 301}$ production stopped progression of neuronal loss but was surprisingly ineffective in halting further accumulation of NFTs. The data from this and other studies served as a basis for further refinement of the amyloid cascade hypothesis to incorporate the idea that some facets of the cascade may become self-propelling and independent from the initial trigger (Golde et al, 2011; Herrup, 2010).

It is becoming clear not only that the amyloid-cascade hypothesis must be revised but also that non-amyloid factors, including some functions of $A D$-related genes, may contribute significantly to AD. Potential mechanisms that could be operative in the pathogenesis of $\mathrm{AD}$ include defective endolysosomal trafficking, altered intracellular signaling cascades, or impaired neurotransmitter release (Pimplikar et al, 2010). An integrated view of the amyloiddependent and -independent mechanisms could promote molecular understanding of $\mathrm{AD}$ pathogenesis and help reconcile the findings that cannot be explained solely by the amyloid hypothesis.

A discrepancy between the results received in preclinical models and the results of clinical trials serves as a call to revisit our theoretical views and make some adjustments. When such discrepancies happen too often and in too big trials, this serves as a call for a paradigm shift that questions every stage of translation - from how we model the disease to how we run clinical trials.

In the following sections, we will use some examples of $\mathrm{AD}$ therapeutics to discuss whether preclinical studies in transgenic models could have predicted the limitations in efficacy and side effects that we were so disappointed to observe in recent clinical trials.

\section{CURRENT THERAPIES FOR AD}

\section{Cholinergic Hypothesis of AD}

Despite substantial progress in understanding the molecular mechanisms and neurobiology of $\mathrm{AD}$, recent therapies are based on early advances in our understanding of the pathology and biochemistry of AD brains. Early histological studies showed a severe loss of cholinergic markers in the cerebral cortex (Bowen et al, 1976; Davies and Maloney, 1976) that were correlated with senile plaques and dementia scores in AD (Perry et al, 1978). Further discoveries revealed that brains of patients with advanced $A D$ are characterized by severe loss of cholinergic cells, providing 
major inputs to the cortex and hippocampus: the nucleus basalis and septal nuclei (Whitehouse et al, 1982). These studies established the cholinergic hypothesis of AD (Bartus et al, 1982; Coyle et al, 1983) that served as a rationale for the development of acetylcholinesterase inhibitors (AChEIs) as a treatment prolonging the action of $\mathrm{ACh}$ at the postsynaptic cholinergic receptors and enhancing cholinergic function. More recently, AChEIs have been shown to have a number of additional effects that potentially have disease-modifying qualities such as neuroprotection and modulation of the $\beta$-amyloid pathway through activation of nicotinic ACh receptors (Francis et al, 2005; Shimohama and Kihara, 2001). Activation of the M1 muscarinic receptors (M1 mAChR; Digby et al, 2010) also has diseasemodifying potential, as M1-selective muscarinic agonists have been shown to decrease $\mathrm{A} \beta$ levels and tau hyperphosphorylation in vitro (for review see Fisher, 2007) and to rescue cognitive deficits and decrease $\mathrm{A} \beta 42$ and tau pathologies in relevant in vivo models (rabbits-Beach et al, 2001; $3 \times \mathrm{TgAD}$ mice-Caccamo et al, 2006).

Treatment with AChEIs, however, results in a modest therapeutic effect, only temporarily halting disease progression (Lanctot et al, 2003a; Rogers et al, 1998). The rather mild effect of AChEIs on memory deficits is not surprising considering early studies in aging monkeys that, like humans, develop neuritic plaques. These studies showed a very narrow range of effective concentrations of AChEIs that could moderately improve memory performance (Davis et al, 1978). The determination of appropriate doses can be even more complicated by a dramatic interindividual variability in the optimal dose effective in aged subjects (monkeys and humans) (Bartus, 1979; Davis et al, 1979). When translated into the clinic, this narrow dose-response characteristic of AChEIs could result in a mild average response in a population of $\mathrm{AD}$ patients, with only some patients showing cognitive improvement (responders) due to a particular stage of cholinergic decline (Sabbagh and Cummings, 2011) or other individual characteristics (Lanctot et al, 2003a).

Recently it started to be recognized that the benefits from treatment for dementia, and of AChEI treatment in particular, are more complex than an improvement on a cognitive measure (Cappell et al, 2010; O'Brien and Burns, 2010). In a situation where the mechanism-based treatments are not available, any treatment, even with relatively low benefits, is highly valuable for patients and caregivers, and can make an important difference to their quality of life. In addition, beneficial effects of AChEIs on behavioral symptoms of $\mathrm{AD}$ began to be appreciated (for review see Pinto et al, 2011), although none of these treatment effects is large (Birks, 2006), These neuropsychiatric behaviors (physical aggression, screaming, restlessness, anxiety, depression, apathy, agitation, hallucinations, delusions, and sleep disturbances) have serious consequences for patients and caregivers, worsening their quality of life and resulting in earlier institutionalization (Black and Almeida, 2004). AChEIinduced amelioration of neuropsychiatric symptoms in $\mathrm{AD}$ patients can be related to the well-known role of the cholinergic system in attention (Olton and Feustle, 1981; Voytko et al, 1994) and the emergent link between attention deficits and development of at least some neuropsychiatric symptoms (Brousseau et al, 2007; Pinto et al, 2011).

\section{Cholinergic Abnormalities in Models of Amyloidosis}

Although the cholinergic hypothesis and experimental bases for AChEI treatment for AD were established well before the era of modeling $\mathrm{AD}$ in mice, transgenic mice proved to be valid models of $\mathrm{AD}$-related cholinergic abnormalities, with high face and predictive validity (Caccamo et al, 2006; Oddo and LaFerla, 2006). For example, APPswe/PS1dE9 transgenic mice show age-related brain amyloidosis (Borchelt et al, 1997) and, with a later onset, significant decreases in cholinergic markers in the cerebral cortex (Liu et al, 2008). As these mice do not have tau-related pathology, these data indicate that processes resulting in $\mathrm{A} \beta$ amyloidosis are sufficient for deterioration of cholinergic function. As in $\mathrm{AD}$ patients (Davis et al, 1999; DeKosky et al, 2002; Gilmor et al, 1999), the cholinergic deficit is not present in these mice until late in the course of amyloidosis. Furthermore, in parallel to observations in AD brains (Davis et al, 1979; Rossor et al, 1980), the APPswe/PS1dE9 mice showed decreases in somatostatin levels in the cortex and hippocampus (Savonenko et al, 2005b). Somatostatin is known to regulate the level of expression of neprilysin, a peptidase that catalyzes the proteolytic degradation of $\mathrm{A} \beta$ (Saito et al, $2005)$. Owing to this positive feedback loop that results in increased $\mathrm{A} \beta$ levels, deficiencies in somatostatin could exert additional disease-modifying effects. The deficits in somatostatin levels in the APPswe/PS1dE9 mice do not correlate with cholinergic markers, suggesting that different brain systems can respond to $\mathrm{A} \beta$ toxicities through independent mechanisms. These data are also consistent with findings in humans showing that $\mathrm{AD}$-related degeneration involves multiple neuronal populations.

\section{$A D$ is a Failure of Multiple Neurotransmitter Circuits}

In addition to the degeneration of cholinergic neurons, $\mathrm{AD}$ is associated with the early and progressive degeneration of monoaminergic (MAergic) neurons (serotonergic (5-HT) neurons in the raphe and the noradrenergic neurons in the locus coeruleus; for review see Liu et al, 2008). Mouse models of amyloidosis (without obvious neurofibrillary pathology) demonstrate that mechanisms related to $\mathrm{A} \beta$ production/accumulation are necessary and sufficient for degeneration of neurotransmitter neurons (Liu et al, 2008). MAergic neurodegeneration in the APPswe/PS1dE9 mice starts at axon terminals and progresses to cell bodies. Degeneration starts at MAergic afferents located in the cortical/hippocampal areas with $\mathrm{A} \beta$ pathology and then leads to the loss of MAergic neuronal cell bodies by 
mechanisms similar to distal axonopathy. This overall pattern of neurodegeneration is consistent with findings in $\mathrm{AD}$, in which MAergic neuronal loss occurs without local A $\beta$ pathology (German et al, 1992; Marcyniuk et al, 1986; Parvizi et al, 2001). In addition, progression of MAergic neurodegeneration and cholinergic deficits in APPswe/ $P S 1 \triangle E 9$ mice coincides with the onset and the progression of cognitive abnormalities, with episodic-like memory being the most sensitive to these insults (Liu et al, 2008; Savonenko et al, 2005b).

The nature of $\mathrm{AD}$ as a failure of multiple neurotransmitter systems was recognized as the main reason for low efficacy of AChEIs even at the time when the cholinergic hypothesis was first formulated. 'It may be necessary to simultaneously improve the balance between the cholinergic and other neurotransmitter systems in order to substantially reduce behavioral impairments' (Bartus et al, 1982). Almost 30 years later, this statement still outlines directions for future research. Extensive literature from rodent models indicates that deficits in a single neuromediator system (reproduced by a pharmacological blockade or lesion) might be necessary but not sufficient to reproduce cognitive impairment (for review see Kenton et al, 2008). Simultaneous pharmacological blockade of at least two neuromediator systems results in more dramatic and more easily detectable memory deficits (Kenton et al, 2008). These experimental data support the idea that when multiple neurotransmitter systems fail, amelioration of cognitive impairment requires treatments targeting multiple systems.

Recent attempts to combine AChEI treatment with memantine, the only other class of FDA-approved drugs for treatment of moderate-to-severe $\mathrm{AD}$, yielded mixed results. Treatment with memantine alone, as in the case of AChEIs alone, brings only modest cognitive and global improvements, including amelioration of delusions, agitation/aggression, and irritability (Gauthier et al, 2008; Mecocci et al, 2009). One of the first studies of combination therapy with memantine and donepezil (one of the AChEIs) showed an improvement in cognitive and non-cognitive outcomes as compared with donepezil alone (Tariot et al, 2004). A recent observational study supported additional benefits from combination therapy by demonstrating a longer delay in admission to residential care (Lopez et al, 2009). However, another study demonstrated no additional benefits from combination therapy (Porsteinsson et al, 2008; see also Schneider et al, 2011). These mixed results indicate that attempts to affect multiple neurotransmitter systems are not an easy task. Variability in disease progression, relative sensitivities of different neuromediator systems to $\mathrm{A} \beta$ - and tau-related toxicities, and capacity for reversal of neurodegeneration at different stages of the disease are only some of the questions to address on the way to successful combination therapies. The existence of genetically modified models of $\mathrm{AD}$ will help to test critical assumptions as to the efficacy and side effects of the treatments, as well as investigate mechanisms and new targets for treatments.
MAJOR DIRECTIONS OF MECHANISMBASED THERAPEUTICS DEVELOPMENT

There are several strategies that have recently been investigated for possible disease-modifying effects in AD. Some of them include drug targets focused on amyloid processing, including inhibition of $A \beta$ production, facilitation of $\mathrm{A} \beta$ breakdown, or clearance and interference with $\mathrm{A} \beta$ oligomerization (Citron, 2010). Tau-focused therapies have started to be developed, including drugs inhibiting tau phosphorylation or stabilizing microtubules (Schneider and Mandelkow, 2008). There has also been an interest in developing anti-inflammatory and neurotrophic/neuroprotective agents or dietary vitamin supplementation (Klegeris et al, 2007). Despite numerous ongoing clinical trials, of date no experimental therapeutics have survived the ultimate test of a phase III clinical trial. Among the most recent failures are trials with AN1792 (active anti- $\mathrm{A} \beta$ immunization), Dimebon (an antihistamine with additional multiple mechanisms of action, for review see Okun et al, 2010), Ginkgo biloba (an anti-oxidant), tarenflurbil (a $\gamma$-secretase modulator), and semagacestat (a $\gamma$-secretase inhibitor, GSI). Most of these experimental therapeutics, particularly those focused on antiamyloid strategies, have been validated in mouse models of amyloidosis. Below we will discuss some of these experimental therapeutics and whether limitations in their efficacy and side effects can be observed in $\mathrm{AD}$ mouse models.

\section{THERAPEUTICS TARGETING A $\boldsymbol{\beta}$ CLEARANCE}

\section{Active Immunization with $A \boldsymbol{\beta}$}

Early pioneering studies by Schenk et al (1999) showed that active immunization with $\mathrm{A} \beta$ peptide attenuates levels of $\mathrm{A} \beta$ peptides and plaques in the brain of an APP transgenic model of AD (PDAPP mice). Importantly, preclinical efficacy in ameliorating $\mathrm{A} \beta$ loads was demonstrated for young animals, in which immunization essentially prevented the development of $\mathrm{A} \beta$ amyloid plaque formation, as well as in older animals. In the latter, the treatment started after the onset of plaque deposition but was effective in markedly reducing the extent and progression of $\mathrm{AD}$-like neuropathologies (Schenk et al, 1999). Not long thereafter, the first human trial of AD immunotherapy with AN1792 was attempted, in which an $\mathrm{A} \beta 1-42$ synthetic peptide with the QS21 adjuvant was administered parenterally to patients with mild-to-moderate AD. However, the trial had to be stopped because of the development of aseptic meningoencephalitis as a complication of the vaccine (Orgogozo et al, 2003; Senior, 2002). Anti-A $\beta$ antibodies raised in $\mathrm{AD}$ patients as a result of active immunization recognized $\beta$-amyloid plaques, diffuse $\mathrm{A} \beta$ deposits and vascular $\beta$-amyloid in brain blood vessels (Hock et al, 2002). T-cell and microglial activation have been suspected as potential 
mechanisms of meningoencephalitis (Orgogozo et al, 2003). Indeed, postmortem analysis of brain sections revealed decreased $\mathrm{A} \beta$ plaques in neocortex regions associated with activated microglia and T-cell infiltrates in the CNS, as compared with unimmunized patients with $\mathrm{AD}$ (Nicoll et al, 2003).

\section{Discrepancies Between Preclinical and Clinical Outcomes of Anti-A $\beta$ Active Immunization}

Meningoencephalitis, a side effect of the active vaccination protocol, had not been expected from preclinical mouse models, raising serious concerns that these models lack predictive validity for clinical trials. Shortly before the discontinuation of the AN1792 clinical trial, it was recognized that mouse models used at the preclinical stages were mostly on a strain background $(\mathrm{C} 57 \mathrm{Bl} / 6)$ that is a rather low responder to $\mathrm{A} \beta$ immunization (Das et al, 2003; Spooner et al, 2002). Further studies revealed that this strain of mice also has low T-cell reactivity due to a low-affinity T-cell epitope presented by the specific I- $\mathrm{A}^{\mathrm{b}}$ MHC class II allele (Monsonego et al, 2006). Presence of another MHC class II haplotype $\left(\mathrm{I}-\mathrm{A}^{\mathrm{s}}\right)$, as is found in the SJL mouse strain, was sufficient to mount a significant $\mathrm{A} \beta$-specific $\mathrm{T}$-cell response when tested in vitro but did not result in T-cell activation and migration to the CNS when tested in vivo in an APP transgenic model (Monsonego et al, 2006). Additional studies spurred by the differences in propensity to T-cell-mediated encephalitis observed in $\mathrm{AD}$ patients (the AN1792 clinical trial), and AD mouse models established critical roles of MHC class II and IFN- $\gamma$ proteins in supporting activation and migration of $\mathrm{T}$ cells, elucidated the impact of different $\mathrm{A} \beta$ epitopes in T-cell and B-celldependent $\mathrm{A} \beta$ clearance, and resulted in new and better models to investigate efficacy and side effects of secondgeneration immunization approaches (for review see Lemere and Masliah, 2010; Perry et al, 2010).

Another discrepancy between preclinical and clinical outcomes of active anti-A $\beta$ immunization involves effects on functional outcomes after removal/amelioration of $\mathrm{A} \beta$ deposition. Early preclinical studies in mice showed that vaccination-induced amelioration of $\mathrm{A} \beta$ plaques coincided with a significant improvement in memory tested in different cognitive tasks, such as reference memory in the Morris water maze (Janus et al, 2000) and working memory in the radial water maze (Morgan et al, 2000) or radial dry maze (Sigurdsson et al, 2004). Although initial findings based on a small number of patients from the Phase II AN1792 clinical trial were promising, showing that patients who generated high titers of the anti-A $\beta$ antibodies appeared to exhibit a slower decline in several functional measures (Hock et al, 2003), full analyses of the Phase II data that included the placebo group did not confirm any positive effect on cognitive decline (Gilman et al, 2005). Long-term clinical follow-up and neuropathological postmortem studies (original Phase I trial) supported this conclusion and showed that even almost complete $\mathrm{A} \beta$ plaque removal in immunized patients resulted in no differences in time to severe dementia (Holmes et al, 2008).

The question of why there was clear amelioration in cognitive outcomes in preclinical but not clinical studies is challenging but important to address, as investigation into mechanisms of these differences might bring us closer to understanding the mechanisms of the disease. The most recent update on the neuropathology in cases from the original Phase I trial reports significant removal of $\mathrm{A} \beta$ plaques and plaque-associated tau-positive dystrophic neurites but no differences between immunized and control $\mathrm{AD}$ cases in the density of phospho-tau-positive neuronal bodies (a marker for Braak Stages; Boche et al, 2010). As immunization was initiated at the stage of mild-tomoderate $\mathrm{AD}$, corresponding to Braak stages III-IV, lack of differences in the Braak stage at the time of death (9 out of 10 cases were at the Braak stage VI) indicates that NFT pathology may have been progressing despite successful amelioration of $\mathrm{A} \beta$ plaques (Boche et al, 2010). An important analogy to these findings is data from a mouse model with conditional overexpression of mutated tau (Tet-off:Tau ${ }_{P 301}$ mice; Santacruz et al, 2005). These mice successfully developed NFTs; however, when production of $\mathrm{Tau}_{P 301}$ protein, an initiator of NFT formation, was genetically inhibited, accumulation of NFTs continued (Santacruz et al, 2005). These preclinical data are an experimental demonstration of the idea that some aspects of the pathological cascade in $\mathrm{AD}$ may become independent of the initial trigger (Golde et al, 2011; Herrup, 2010).

If this is true, then the removal of $\mathrm{A} \beta$ plaques or NFTs after the pathological cascades of neuronal toxicities have already been initiated might not bring significant benefits in functional outcomes.

Analyses of synaptic markers (synaptophysin) in the cortex and hippocampus of small numbers of immunized and control $\mathrm{AD}$ cases revealed no protective benefit to synapses after immunization (Boche et al, 2010). In contrast to this outcome, active anti-A $\beta_{1-42}$ immunization in an $\mathrm{AD}$ mouse model (PDAPP mice) resulted in significant protection against the progressive loss of synaptophysin in the hippocampal molecular layer and frontal neocortex (Buttini et al, 2005). Differences between data in human and mouse models might be interpreted as limitations of the mouse models in terms of their face validity. Indeed, the mouse models used to test the effects of anti-A $\beta_{1-42}$ immunization on synaptophysin or cognitive deficits are good models of $\mathrm{A} \beta$ amyloidosis but lack tau-related pathology. One might argue that rescue of the synaptic and cognitive deficits in these mouse models is possible because of the absence of concomitant tau pathology. This hypothesis is testable in mouse models that combine at least some aspects of $\mathrm{A} \beta$ amyloid- and tau-related pathologies. Indeed, when active anti- $\mathrm{A} \beta_{1-42}$ vaccination was used in the $3 \times \mathrm{Tg}-\mathrm{AD}$ mice that developed both significant $\mathrm{A} \beta$ amyloidosis and tau pathology, cognitive improvement in these mice coincided with concomitant decreases in soluble 
levels of $\mathrm{A} \beta$ and tau peptides (Oddo et al, 2006). When the same mouse model was subjected to shorter protocols of immunization in which soluble $\mathrm{A} \beta$ levels were decreased but soluble tau levels remained unchanged, there was no cognitive improvement (Oddo et al, 2006). These preclinical data indicate that active immunization can bring beneficial effects on cognition even when $\mathrm{A} \beta$ - and tau-related pathologies coexist; however, for an anti-A $\beta$ immunization strategy to be effective, it should result in concomitant reductions in the levels of soluble $\mathrm{A} \beta$ and tau. Turning to the most recent reports on the neuropathology of $\mathrm{AD}$ cases after the anti-A $\beta$ vaccination trial, it is important to note that although it is difficult to make any analogies between changes in tau in human $v s$ mouse cases (due to different antibodies and protocols used), what is strikingly different from the $3 \times \mathrm{Tg}-\mathrm{AD}$ mice is that in $\mathrm{AD}$ patients the immunization increased rather than decreased levels of soluble $\mathrm{A} \beta$.

The increased levels of soluble $\mathrm{A} \beta$ in the brains of immunized AD patients might be not surprising considering the fact that the anti-A $\beta$ antibodies produced by these patients clearly fail to react with soluble and oligomeric $\mathrm{A} \beta$ (Hock et al, 2002). In contrast, the anti-A $\beta$ antibodies produced by mice as a result of active immunization detect monomeric, oligomeric, and fibrillar A $\beta$ (McLaurin et al, 2002). Sufficient affinity for soluble and particularly oligomeric $\mathrm{A} \beta$ might be a condition necessary for the clinical efficacy of the antibody (Haass, 2002), as $\mathrm{A} \beta$ oligomers have been shown to have significant synaptic toxicity (Walsh et al, 2002). The evidence of increased soluble/oligomeric $\mathrm{A} \beta$ in $\mathrm{AD}$ patients after anti-A $\beta_{1-42}$ vaccination (Boche et al, 2010), as well as the correlation between levels of $\mathrm{A} \beta$ oligomers and cognitive dysfunction in $\mathrm{AD}$ (Tomic et al, 2009), indicates that low reactivity of human antibodies to soluble/oligomeric $\mathrm{A} \beta$ may be particularly important in explaining negative functional outcomes in the AN1792 clinical trial.

\section{Passive Anti-A $\boldsymbol{\beta}$ Immunization}

To date, the most exciting findings regarding the effects of anti-A $\beta$ immunotherapy in rescuing cognitive deficits comes from a study in which acute systemic treatment with anti-A $\beta$ antibody reversed memory deficits in an APP mouse model (Dodart et al, 2002). Importantly, as the duration of the treatment was so short, the memory improvement was not associated with any detectable changes in the brain $\mathrm{A} \beta$ burden, indicating that $\mathrm{A} \beta$ plaque removal is not necessary for the beneficial effect of immunization. Instead, a dramatic increase in $\mathrm{A} \beta$ concentration was observed in the blood (Dodart et al, 2002), leading to the hypothesis that a soluble pool of $\mathrm{A} \beta$ that can be easily removed from the brain is responsible for cognitive deficits. A significant correlation between an antibody-induced increase in $\mathrm{A} \beta$ plasma concentration and $\mathrm{A} \beta$ amyloid load in the brain (DeMattos et al, 2002) suggests that there is a dynamic equilibrium between a removable pool of $\mathrm{A} \beta$ species and aggregated $\mathrm{A} \beta$ sequestered into plaques. This equilibrium might explain correlations observed between $\mathrm{A} \beta$ plaque load and memory deficits in different APP transgenic models (Arendash et al, 2001; Chen et al, 2000; Gordon et al, 2001; Janus et al, 2000). The studies of acute passive immunization (DeMattos et al, 2002; Dodart et al, 2002; Kotilinek et al, 2002) seriously challenged the original role of $\mathrm{A} \beta$ plaques in mediating memory deficits and intensified investigations into which type of 'soluble' non-plaque $\mathrm{A} \beta$ species is responsible for cognitive toxicity. A number of groups initiated the development of conformation-specific anti-A $\beta$ antibodies, with higher affinity to oligomeric species (Kayed et al, 2007; Kayed et al, 2003; Lee et al, 2006; O’Nuallain and Wetzel, 2002). Some of these antibodies have also been demonstrated to acutely improve learning and memory in APP transgenic mice (Lee et al, 2006).

\section{Efficacy and Side Effects: Expectations from Preclinical Passive Anti-A $\beta$ Immunization}

The discovery of acute memory improvement after anti-A $\beta$ passive immunization brought a lot of hope that this approach might rapidly reduce cognitive impairment in $\mathrm{AD}$ patients apart from any effect on amyloid deposition. However, further preclinical studies showed significant limitations in the efficacy of acute treatments with anti-A $\beta$ antibodies. Immunization required longer duration of the treatment to be effective in mice of advanced age/amyloid deposition (Chen et al, 2007; Das et al, 2001; Wilcock et al, 2004). Another factor limiting efficacy of anti-A $\beta$ passive immunization has been demonstrated in $3 \times \mathrm{Tg}-\mathrm{AD}$ mice that combine $\mathrm{A} \beta$ plaque- and tau-related pathology. In these mice, immunization-induced amelioration in tau-related pathology seems to be required for memory benefits but is more resistant to change in the short-term window of an acute treatment (Oddo et al, 2006). Recently, data on the effects of single administration of an anti-A $\beta$ antibody (solanezumab) in AD patients became available (Siemers et al, 2010). Importantly, these $\mathrm{AD}$ patients were treated with a humanized version of the murine antibody $\mathrm{m} 266.2$ that was originally used to discover the acute reversal of memory deficits in mouse models (Dodart et al, 2002). As in preclinical studies, a significant dose-dependent increase in concentrations of $\mathrm{A} \beta$ in plasma and CSF was observed after a systemic injection with the antibody in AD patients (Siemers et al, 2010). However, in contrast to original preclinical findings, a single administration of the antibody did not coincide with significant changes in cognitive scores. This negative functional outcome is consistent with expectations from preclinical models showing low efficacy of passive immunization in the setting of advanced amyloidosis and presence of tau pathology, as discussed above. Whether these limitations can be surmounted by long-term passive immunization will be elucidated through Phase III clinical trials that are now in progress (solanezumab, Lilly and bapineuzumab, Elan). 
Preclinical studies elucidated several side effects that can be expected from the passive immunization approach. On the basis of the knowledge that meningoencephalitis is one of the major side effects of anti-A $\beta$ vaccination (Orgogozo et al, 2003), this possible side effect was explicitly investigated in APP mouse models after passive immunization. Indeed, in the Tg2576 APP mouse model, cases of meningoencephalitis were observed after a passive transfer of NAB61 antibody (Lee et al, 2005). Histologically, these cases were consistent with inflammation triggered by antibody binding to $\mathrm{A} \beta$ angiopathy. Another side effect discovered in APP mouse models after passive anti-A $\beta$ immunotherapy is cerebral microhemorrhages associated with amyloid-laden vessels (Pfeifer et al, 2002). Further preclinical studies demonstrated that exacerbation of microhemorrhages depends on antibody recognition of the deposited form of $\mathrm{A} \beta$ (Racke et al, 2005). Antibodies that are raised to different domains of $\mathrm{A} \beta$ (the 3D6 and 10D5-N-terminally directed and 2286- N-terminally directed antibodies) but share high affinity to $\mathrm{A} \beta$ deposits increase vascular $\mathrm{A} \beta$ angiopathy and microhemorrhages (Racke et al, 2005; Wilcock et al, 2004). In contrast, antibody that did not bind deposited $\mathrm{A} \beta$ (m266.2 directed to central domain of $\mathrm{A} \beta$ ) did not result in this complication (Racke et al, 2005). Recent reports from a Phase II clinical trial with bapineuzumab, an anti- $\mathrm{A} \beta$ antibody that is raised against the N-terminal fragment of $\mathrm{A} \beta$ and binds to $\mathrm{A} \beta$ plaques, indicate a low incidence of vasogenic edema that could reflect cerebral amyloid angiopathy and antibody-induced changes in vascular permeability (Salloway et al, 2009). This side effect was more prevalent with increasing dose of the antibody and in APOE $\varepsilon 4$ carriers, indicating that some subgroups of $\mathrm{AD}$ patients may be more prone to antibodyinduced vascular side effects and should be evaluated at a lower dose range in future studies (Salloway et al, 2009). A recent study of anti-A $\beta$ vaccination in APPswe/NOS2 ko mice (Wilcock et al, 2009) pointed to increased vascular expression of eNOS as another factor that can increase susceptibility to microhemorrhages and possibly serve as a basis for interindividual variability in vascular side effects. Recognition of microhemorrhages as a possible side effect from passive immunization approaches led to additional preclinical research in an attempt to find protocols/antibody modifications that would minimize this complication. For example, deglycosylation of antibodies has been shown to retain the memory-enhancing and amyloid-ameliorating properties of the immunotherapy, while attenuating the increased vascular $\mathrm{A} \beta$ deposition and microhemorrhages observed with unmodified IgG (Wilcock et al, 2006).

Passive immunotherapy has a lot of advantages over the active immunization approach, allowing for better control over the duration of treatment, overcoming problems with low responders, and allowing for careful selection of the antibodies to maximize efficacy and minimize serious adverse events. Although some challenges do exist in extrapolating the outcomes of immunization approaches in mutant mice to human trials, preclinical studies that are explicitly designed to analyze possible side effects or limitations in efficacy of the treatment seem to have better predictive validity than the initial 'discovery' studies.

\section{THERAPEUTICS TARGETING A $\boldsymbol{\beta}$ PRODUCTION}

\section{$\beta$-Secretase Inhibition}

After discoveries of mutations associated with familial forms of $\mathrm{AD}$, intensive studies have been initiated to understand the biochemistry and physiology of $\mathrm{A} \beta$ production from its precursor, APP. In the CNS, $\mathrm{A} \beta$ peptides are generated by sequential endoproteolytic cleavages of neuronal APP by BACE1 and $\gamma$-secretase. Because BACE1 cleavage of APP is a critical rate-limiting step in $\mathrm{A} \beta$ amyloidosis, it has been suggested that inhibition of BACE1 would be an attractive strategy to ameliorate $\mathrm{A} \beta$ deposition in AD (Citron, 2002; Vassar, 2002). Supporting this notion are studies demonstrating that deletion of BACE1 prevents $\mathrm{A} \beta$ secretion in cultured neurons and in the brain (Cai et al, 2001; Luo et al, 2001; Roberds et al, 2001 ), and that mutant $A P P$ mice lacking BACE1 neither develop $\mathrm{A} \beta$ plaques nor $\mathrm{A} \beta$-related memory deficits (Laird et al, 2005; Ohno et al, 2004).

Original optimism for the development of pharmacological BACE1 inhibitors was based on the successful precedent in drug development of an inhibitor of an HIV protease that is, such as BACE1, an aspartic protease. However, the discovery of such inhibitors of BACE1 has proved to be particularly difficult because of the $\beta$-secretase active site for substrate recognition has a long cleft that is structurally incompatible with the requirement for smallmolecule blood-brain barrier (BBB)-penetrating inhibitors with high potency and selectivity (for review see Ghosh et al, 2008). However, in the last few years, significant advances have been made, and one of the first candidates (CTS21166, CoMentis) was moved into a Phase I clinical trial. This trial aimed to evaluate the safety and tolerability of single ascending doses of CTS21166 following intravenous administration (clinicaltrial.gov).

\section{Preclinical Perspective on the Efficacy and Side Effects of BACE1 Inhibition}

In preclinical studies, some of the BACE1 inhibitors that were conjugated to a carrier peptide to facilitate penetrating the $\mathrm{BBB}$ demonstrated the ability to reduce brain $\mathrm{A} \beta$ levels after systemic injections in APP transgenic mice (Chang et al, 2004). The most recent study of a new generation of BACE1 inhibitors (without conjugated carriers) showed brain penetration sufficient to reduce interstitial concentration (ISF) of $\mathrm{A} \beta$ in the brain and reduction of $\mathrm{A} \beta$ in plasma (Chang et al, 2011). In addition, treatment with this inhibitor was effective in ameliorating cognitive deficits in the Tg2576 model (Chang et al, 2011). Although the size effect of inhibition of new $\mathrm{A} \beta$ production was significant 
( $\sim 50$ and $60 \% \mathrm{~A} \beta$ reduction in ISF and plasma, respectively), there were no acute effects on memory deficits. Treatment with the BACE1 inhibitor required at least 4 months for cognitive benefits to be detectable (Chang et al, 2011). Another important finding from this study is a modulation of efficacy with age: mice older than 16 months of age were not able to benefit from the treatment as younger mice did. The decrease in efficacy with advanced age/disease stage is in agreement with earlier studies in which BACE1 inhibition was modeled by genetic ablation of a BACE1 gene (Laird et al, 2005). Full deletion of BACE1 in an aggressive model of amyloidosis, APPswe;PS1 $\triangle E 9$ mice, prevented both $\mathrm{A} \beta$ deposition and age-associated cognitive abnormalities. However, functional outcomes of partial BACE1 deletion in BACE1 homozygous mice ( $\sim 50 \%$ of BACE1 activity) declined as aging progressed, possibly due to compromised $\mathrm{A} \beta$ clearance mechanisms in aged animals (Laird et al, 2005). Despite of 50\% reduction in BACE1 activity, 20 - to 24-month-old mice had levels of $\mathrm{A} \beta$ deposition as high as in mice with $100 \%$ BACE1 activity.

Another group has recently published data on the effects of a structurally different noncompetitive BACE1 inhibitor (TAK-070) that ameliorated $\mathrm{A} \beta$ pathology and behavioral deficits in Tg2576 mice (Fukumoto et al, 2010). Although the reduction in $\mathrm{A} \beta$ levels was modest, the authors of the study proposed that the increase in $\operatorname{sAPP} \alpha$ by noncompetitive BACE1 inhibition may be an additional benefit, resulting in amelioration of cognitive deficits. In contrast to the previously discussed BACE1 inhibitor (see previous paragraph), TAK-070 resulted in cognitive benefits after shortterm ( 2 weeks) treatment when tested in young Tg2576 mice (5 months of age). Acute efficacy in rescuing cognitive deficits has been documented in young mice of the same mouse model using a passive immunization approach (Kotilinek et al, 2002). Although no testing of TAK-070 effects was presented for older mice, on the basis of other preclinical studies one can expect that the cognitive benefits of TAK-070 might decrease as aging/disease progresses.

Detailed investigation into the efficacy and limitations of partial inhibition of BACE1 is particularly important because complete inhibition of this enzyme could potentially be associated with problems for several reasons. $\mathrm{A} \beta$ may normally have an important role in modulating activities of certain synapses (Kamenetz et al, 2003), and strong BACE1 inhibition may result in $\mathrm{A} \beta$ deficiency below physiological levels. In addition, a number of other putative substrates for BACE1 have been identified, suggesting that BACE1 has multiple physiological functions. $\beta$ - APP-like proteins (APLP1 and APLP2) have been discovered to be processed by BACE1 (Li and Sudhof, 2004; Pastorino et al, 2004) to act via the same nuclear target (Tip60 in a complex with Fe65), suggesting that BACE1 cleavage regulates a common function of APPs and APLPs in neurons (Li and Sudhof, 2004). Other putative substrates of BACE1 might include the LDL receptorrelated protein (LRP; von Arnim et al, 2005); $\beta$-galactoside $\alpha 2,6$-sialyltransferase I (ST6Gal I; Kitazume et al, 2001); the adhesion protein P-selectin glycoprotein ligand-1 (PSGL-1;
McEver and Cummings, 1997); and the $\beta$-subunit of voltagegated sodium channels (VGSC $\beta$; Wong et al, 2005).

The proteolytic role of BACE1 has also been confirmed in the processing of neuregulin 1 (NRG1; Hu et al, 2006; Willem et al, 2006), a ligand for members of the ErbB family of receptor tyrosine kinases, which have numerous roles in the CNS development and functions, including synapse formation, plasticity, neuronal migration, central and peripheral myelination of axons, and the regulation of neurotransmitter expression and function (Falls, 2003; Michailov et al, 2004). In addition to these physiological functions, NRG1 is one of the first genes to have been linked to an increased risk of schizophrenia (Stefansson et al, 2002), and mice with complete genetic deletion of BACE1 demonstrate numerous behavioral traits consistent with schizophrenia-related endophenotypes (Savonenko et al, 2008). Study of direct infusion of a $\beta$-secretase inhibitor into cerebral ventricles of adult mice demonstrated strongly reduced $\mathrm{A} \beta$ levels but no change in the processing of NRG1 (Sankaranarayanan et al, 2008). These data indicate that the role of BACE1 in relation to at least some of its substrates may be developmentally regulated.

Further preclinical studies are necessary to ascertain the efficacy and safety of new BACE1 inhibitors, as well as investigate the limitations in their efficacy as a function of aging and disease progression.

\section{$\gamma$-Secretase Inhibition}

The $\gamma$-secretase complex catalyzes the final cleavage of APPs and has been considered to be a significant target for therapy. As demonstrated by gene-targeting strategies, this complex is critically dependent upon the presence of PS1 and 2, and Pen-2, as well as Nct and Aph-1a (De Strooper, 2003). Both genetic and pharmaceutical lowering of $\gamma$-secretase activity decreases production of $\mathrm{A} \beta$ peptides in cell-free and cell-based systems and reduces levels of $\mathrm{A} \beta$ in mutant mice with $\mathrm{A} \beta$ amyloidosis (Wong and Price, 2005). However, like $\beta$-secretase, $\gamma$-secretase has multiple substrates (for review see De Strooper et al, 2010). The role of presenilins in the cleavage of the Notch receptor was identified before the discovery of its role in APP processing (De Strooper et al, 2010). Interference with Notch signaling has been recognized as a basis for the most important potential side effects of inhibition of $\gamma$-secretase activity. These side effects include gastrointestinal bleeding (van Es et al, 2005), skin cancer (Nicolas et al, 2003), autoimmune (Hadland et al, 2001), and other problems.

Owing to early recognition of interference with Notch signaling, research into the efficacy of new GSIs has usually addressed the possibility of developing side effects due to concomitant changes in Notch signaling. Importantly, Notch inhibition is viewed as an advantage for the treatment of certain types of cancers that have excessive Notch signaling (Rizzo et al, 2008). For these anti-neoplastic agents, the therapeutic strategy is to reach a therapeutic window for GSIs that would allow for therapeutic benefit at 
doses and a duration of treatment small enough to avoid side effects. In $\mathrm{AD}$, initial development of GSIs has also been focused on finding a balance between therapeutic benefits and side effects. However, as $\mathrm{AD}$ therapeutics are required to enter the brain, the BBB permeability of GSIs is an additional hurdle that complicates finding a balance between beneficial effects in the CNS and side effects in the periphery. The latest research on GSIs for AD has been focused on how to dissociate the activity of the $\gamma$-secretase complex toward APP and Notch.

Recent studies have reported a number of proteins that interact with the $\gamma$-secretase complex and can modulate its activity by changing subcellular compartmentalization, complex maturation, membrane trafficking and so on (for review see De Strooper et al, 2010). A novel secretase-activating protein (GSAP) has recently been discovered (He et al, 2010) that can dramatically and selectively increase the production of $\mathrm{A} \beta$ via a process whereby GSAP interacts with both $\gamma$-secretase and the APP-CTF. Significantly, GSAP neither interacts with Notch nor influences its cleavage or signaling capacities. Moreover, a modulatory role of GSAP has been confirmed in vitro and in vivo. Knockdown of GSAP in a mutant mouse with $\mathrm{A} \beta$ amyloidosis lowers levels of $\mathrm{A} \beta$ and decreases the number of $A \beta$ plaques in APPswe/PS1dE9 mice when initiated before the onset of plaque deposition (He et al, 2010). Whether and to what extent this experimental strategy is effective when initiated at more advanced stages of $\mathrm{A} \beta$ amyloidosis or in mice of advanced ages has not yet been tested. The significance of this finding is that manipulations with GSAP may allow lowering of $\mathrm{A} \beta$, without affecting other critical functions of $\gamma$-secretase.

\section{Discrepancies between Preclinical and Clinical Outcomes of GSIs}

A variety of companies have attempted to identify and develop potent and selective GSIs. Some of these GSIs reached Phase II and III clinical trials (for review see Henley et al, 2009); however, to date none has been successful. One of the most recent disappointments with GSIs were Phase III clinical trials with semagacestat (LY450139, Eli Lilly) that was compared with placebo in more than 2600 patients with mild-to-moderate AD (Figure 1). Trials were started in March-September 2008 and halted in August 2010 because of worsening observed in cognitive assessments and activities of daily living as compared with the placebo group (http://www.lilly.com). In addition, an increased risk of skin cancer was observed (http://www.lilly.com). An increased incidence of skin cancers could be expected from preclinical studies with genetic inhibition of $\gamma$-secretase (Li et al, 2007); however, Phase I and II studies did not report this side effect, probably because of a shorter duration of the treatment ( $<14$ weeks). Phase II studies showed no significant cognitive effect in patients with mildto-moderate $\mathrm{AD}$, and the lack of the effect was attributed to the short duration of the treatment ( $<14$ weeks). If Phase III trials were to confirm an absence of beneficial effect on functional outcomes, this could be explained by the late start of treatment relative to the onset of the disease. Aggregation of $\mathrm{A} \beta$ peptides into oligomers and ultimately into plaques, a process that represents an initial early insult in disease progression, may lead to pathological mechanisms that are relatively independent from the initial trigger or become irreversible (Golde et al, 2011; Herrup, 2010). This assumption predicts that anti- $\mathrm{A} \beta$ therapies will be increasingly ineffective as disease progresses. This view is supported by findings from the AN1793 clinical trial, in which almost complete $\mathrm{A} \beta$ plaque removal in immunized patients resulted in no differences in time to severe dementia (Holmes et al, 2008). What is most alarming from the clinical trials with semagacestat is not a lack of cognitive benefits but actually aggravation of cognitive decline; what is most intriguing is whether such negative outcome could be expected from preclinical studies or early phases of clinical studies.

Semagacestat (LY-450139) is a highly potent GSI that has been tested extensively in animal models and humans (for review see Henley et al, 2009) (Figure 1). In an APP transgenic mouse model (PDAPP), LY-450139 lowered brain, CSF, and plasma A $\beta$ (May et al, 2004). Importantly, when LY-450139 was administered to WT mice (not expressing high levels of mutated APP), a GSI-induced decrease in plasma $\mathrm{A} \beta$ concentration was followed by a significant increase at later time points. Similar dynamics were observed in beagle dogs (for review see Henley et al, 2009). These data were interpreted as a possible effect of the GSI in the periphery, as in both WT mice and dogs increases in plasma $\mathrm{A} \beta$ were not associated with simultaneous elevations in the CSF or the brain. The pharmacodynamics of LY450139 and its effects on the CSF and the plasma $\mathrm{A} \beta$ were extensively studied in healthy volunteers. A single dose of this compound leads to biphasic changes in the CSF levels of $\mathrm{A} \beta$, particularly $\mathrm{A} \beta_{1-42}$, with an initial decrease in $\mathrm{A} \beta$ levels reaching plateau between 6 and $15 \mathrm{~h}$ after the treatment, followed by an increase between 20 and $32 \mathrm{~h}$ (Bateman et al, 2009). In contrast to previous interpretations (see above), these data strongly suggested an involvement of central effects of the GSI in mediating a biphasic $\mathrm{A} \beta$ response. Importantly, the biphasic dynamics of the CSF A $\beta$ concentration was dose dependent and more pronounced for $\mathrm{A} \beta_{1-42}$ than for $\mathrm{A} \beta_{1-40}$ (Bateman et al, 2009). As to the dose used in the Phase III clinical trials $(100-140 \mathrm{mg})$, the GSI resulted in a predominant decrease in $\mathrm{A} \beta_{1-40}$, followed by a second phase of increase in $\mathrm{A} \beta_{1-42}$. The biphasic dynamics of A $\beta$ in response to LY450139 were reported earlier in the plasma of healthy volunteers after a single oral dose of the drug (Siemers et al, 2005). In this case, an initial dose-dependent decrease in plasma $\mathrm{A} \beta$ was followed by a dramatic $(>300 \%)$ increase. The authors suggested that the increase in plasma $\mathrm{A} \beta$ can be caused by rising concentrations of substrate for $\gamma$-secretase during the period of enzyme inhibition, which results in an increase in $\mathrm{A} \beta$ after LY450139 is no longer present (Siemers et al, 2005). 


\section{6-2001}

The "A $\beta$ rise" effect of GSIs: the same GSI increases $A \beta$ at low concentrations and decreases it at higher concentrations ${ }^{1}$.

2004

Acute $L Y$ decreases plasma $A \beta$ in APP transgenic mice (PDAPP), but shows a biphasic response in control mice ${ }^{2}$

\section{4}

Chronic LY lowers brain, CSF and plasma $A \beta$ in PDAPP mice $^{3}$

\section{4-2005}

LY shows a biphasic response of $A \beta$ in plasma in beagle dogs 4

No changes in brain and CSF after 12 months of LY treatment ${ }^{4}$.

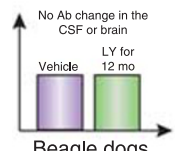

Beagle dogs
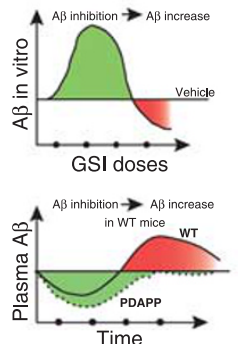

2006

LY shows a biphasic response of $A B$ in plasma in guinea pigs ${ }^{5}$.

2008

APP transgenic mice can exhibit a misleading degree of GSI inhibitory activity due to the lack of the "A $\beta$ rise" effect of GSIs ${ }^{12}$.

\section{9}

$L Y$ results in a long-lasting decrease in the density of dendritic spines in the brains of wild-type mice ${ }^{13}$.
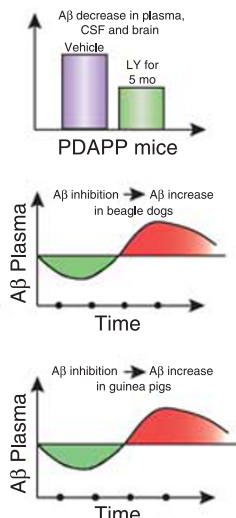

\section{PHASE I - II}

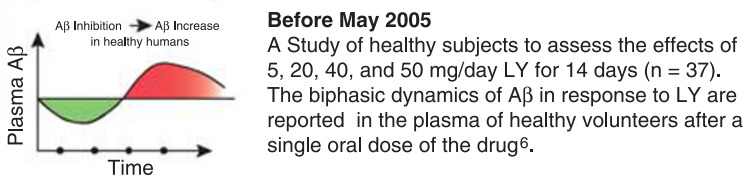

\section{AB Inhibition in AD patients Before May 2005}

$\uparrow^{A B \text { Inhibition in } A D \text { patients }} \quad$ A study of patients with mild to moderate $A D$ to assess the effects of $30-->40 \mathrm{mg} /$ day $L Y$ for 5 weeks $(n=70)$. $A$ significant decrease in plasma $A \beta$ in response to $L Y$ is reported after a final dose of the drug. No changes in CSF A $\beta^{9}$.

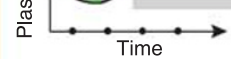

\section{April - Dec 2004}

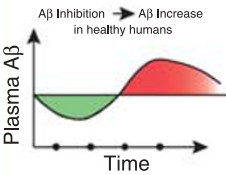

A study of healthy subjects to assess the effects of 60 100 , and $140 \mathrm{mg} /$ day of a single oral dose of $L Y(n=37)$. The biphasic dynamics of $A \beta$ in response to $L Y$ are reported in the plasma of healthy volunteers after a single oral dose and 14 weeks of treatment ${ }^{8}$

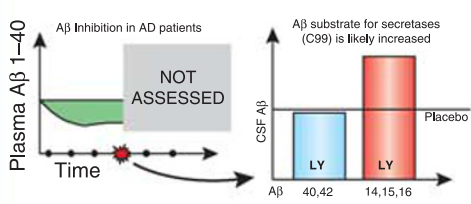

Oct 2005-Dec 2006

A study of patients with mild to moderate $A D$ to assess the effects of $100,140 \mathrm{mg} /$ day LY for

14 weeks $(n=45)$. A significant decrease in plasma A $\beta$ 40, 42 is reported after 14 weeks of LY treatment ${ }^{10}$ No changes in CSF Ab40,42, but a significant increase in $A \beta 14,15,16^{11}$.

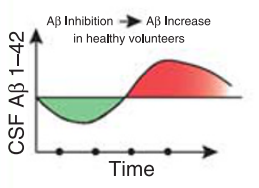

July 2006-Sept 2007

A study of healthy subjects to assess the effect of 100 140 , and $280 \mathrm{mg}$ of single oral dose of $L Y(n=27)$.

The biphasic dynamics of $A B$ in response to $L Y$ is reported in the CSF of healthy volunteers after a single oral dose of the $\mathrm{drug}^{7}$.

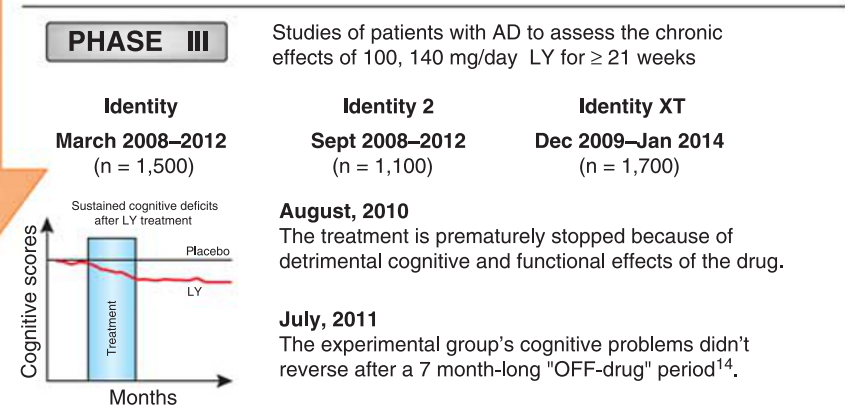

Figure 1. Timeline of some of the major findings in preclinical and clinical stages of the development of semagasestat. Preclinical data on limitations in efficacy of semagasestat related to aging and initial plaque load (see text) are not included in this scheme. GSI, $\gamma$-secretase inhibitor; LY, LY450139 (semagasestat); swe, Swedish mutation; WT, wild type. References: (1) Durkin et al, J Biol Chem, 1999. 274: p. 20499-504; (2) May et al, Neurobiol Aging, 2004. S1: p. S65; (3) Ness et al, Neurobiol Aging, 2004. S1: p. S238; (4) Lily's data on file - for review see Henley et al, Expert Opin Pharmacother, 2009. 10: p. 1657-64; (5) Lanz et al, J Pharmacol Exp Ther, 2006. 319: p. 924-33; (6) Siemers et al, Clin Neuropharmacol, 2005. 28: p. 126-32; (7) Bateman et al, Ann Neurol, 2009. 66: p. 48-54; (8) Siemers et al, Clin Neuropharmacol, 2007. 30: p. 317-25; (9) Siemers et al, Neurology, 2006. 66: p. 602-4; (10) Fleisher et al, Arch Neurol, 2008. 65: p. 1031-8; (11) Portelius et al, Alzheimers Res Ther, 2010. 2: p. 7; (12) Burton et al, J Biol Chem, 2008. 283: p. 22992-3003; (13) Bittner et al, J Neurosci, 2009. 29: p. 10405-9; (14) Siemers, Alzheimer's Association International Conference, 19 July 2011, Paris, France.

The 'A $\beta$ rise' effect of GSIs has been widely observed as a phenomenon when the same GSI increases $\mathrm{A} \beta$ at low concentration and decreases it at higher concentrations (Citron et al, 1996; Henley et al, 2009; Lanz et al, 2006; Zhang et al, 2001). Importantly, the extent of GSI-induced $\mathrm{A} \beta$ rise has been shown to be more pronounced for $\mathrm{A} \beta_{1-42}$ than for $\mathrm{A} \beta_{1-40}$ peptides (Burton et al, 2008). These data are in agreement with findings in human volunteers after a single dose of LY450139 (Bateman et al, 2009). Considering that $\mathrm{A} \beta_{1-42}$ has fast aggregation kinetics, even small increases in $\mathrm{A} \beta_{1-42}$ or $\mathrm{A} \beta_{1-42} / \mathrm{A} \beta_{1-40}$ ratio can significantly affect the neurotoxicity of total $\mathrm{A} \beta$ (Kuperstein et al, 2010). Transient increases in CSF and plasma $\mathrm{A} \beta_{1-42}$ concentrations observed in healthy volunteers after LY450139 administration most likely reflect successful clearance of these peptides from the CNS. These GSI-induced increases in $\mathrm{A} \beta$ might not be present in a situation with impaired $\mathrm{A} \beta$ clearance and/or presence of $\mathrm{A} \beta$ plaques. $\mathrm{A} \beta$ plaques, 
because of fast sequestration of soluble $\mathrm{A} \beta$, change the balance between ISF and peripheral compartments (Price et al, 2007). Indeed, detection of changes in the CSF A $\beta$ levels proved to be more difficult in $\mathrm{AD}$ patients, with a majority of studies reporting no significant effects of GSIs, including LY450139, on $\mathrm{A} \beta_{1-42}$ and $\mathrm{A} \beta_{1-40}$ (Portelius et al, 2010). This lack of observed changes is misleading and rather indicates that $\mathrm{A} \beta_{1-42}$ and $\mathrm{A} \beta_{1-40}$ concentrations in the CSF can not be used as biomarkers of the intended drug activity in the $\mathrm{AD}$ brain. In contrast to unchanged levels of $\mathrm{A} \beta_{1-42}$ and $\mathrm{A} \beta_{1-40}$, significant increases were found in the CSF levels of $\mathrm{A} \beta_{1-14}, \mathrm{~A} \beta_{1-15}$, and $\mathrm{A} \beta_{1-16}$ peptides (Portelius et al, 2010). Similar changes in short $\mathrm{A} \beta$ peptides were found in the CSF of APP mouse models after treatment with GSIs and might be explained by an increased amount of substrate (C99 APP-CTF) for $\alpha$-secretase after inhibition of $\gamma$-secretase (for review see Portelius et al, 2010).

Another important nuance in understanding the discrepancies in the effects of GSIs between recent clinical studies and studies in APP mouse models comes from data showing that overexpression of APPs and APPs with Swedish mutation in particular preclude the 'A $\beta$ rise' effect of GSIs (Burton et al, 2008) (Figure 1). Although the exact mechanisms for lack of the GSI-induced $\mathrm{A} \beta$ rise are not clear (high substrate availability and/or GSI potency shift; for review see Burton et al, 2008), the APP transgenic mouse models that were widely used to study the effects of GSIs in the last decade (Tg2576, PDAPP, TgCRND8, and others) resulted in a misleading impression of higher degree of inhibition in $\mathrm{A} \beta$ production. Even in this experimental condition that is favorable for the detection of positive outcomes, the effects of GSIs in reducing brain $\mathrm{A} \beta$ levels were significant when tested in young APP mice but lost efficacy in old APP mice (Abramowski et al, 2008; Lanz et al, 2003). Similar age-related limitations in efficacy of $\gamma$-secretase inhibition were shown by genetic ablations of proteins comprising the $\gamma$-secretase complex (Chow et al, 2010; Li et al, 2007). On the basis of these studies in APP animal models, one might expect that treatment with LY450139 when started in old AD patients with wellestablished $\mathrm{A} \beta$ amyloidosis will not result in reduction of brain $\mathrm{A} \beta$ levels. Considering the ' $\mathrm{A} \beta$ rise' effect of GSI and LY450139 in particular one might expect that LY450139 treatment could increase brain $\mathrm{A} \beta$ levels, including levels of oligomeric $\mathrm{A} \beta_{1-42}$ peptides. The latter outcome would be in agreement with the observed worsening of cognitive symptoms (Figure 1).

\section{FUTURE DIRECTIONS}

Two major disappointments across different experimental treatments for $\mathrm{AD}$ are low drug efficacy and significant side effects. Two other fields of medical research, cancer and infectious diseases, successfully balance efficacy and side effects by development of combination treatments. This idea has already been expressed in the AD field from the time of formulation of the cholinergic hypothesis, but until recently did not result in experimental developments.

Ideally, drug combination should be designed in a way that not only sums the efficacies of single drugs but has the potential to dramatically augment their benefits while canceling side effects. Such design requires detailed molecular understanding of the disease as well as side effects of the drugs. Two recent studies in APP mouse models provided a proof of concept for such combination therapies in AD. As discussed in previous sections, $\beta$ - and $\gamma$-secretases are well-established mechanism-based therapeutic targets for $\mathrm{AD}$; however, strong inhibition of these secretases results in significant side effects. Moderate inhibition of either $\gamma$-secretase or BACE1 provides only modest benefits in reducing $\mathrm{A} \beta$ levels and these benefits decrease with progression of the disease/aging, providing no functional improvements in old mice (Chow et al, 2010; Laird et al, 2005; Li et al, 2007). In a recent study, Chow et al (2010) provided evidence that a moderate inhibition of both secretases modeled by a partial genetic ablation of $B A C E 1$ and Aph $1-\alpha$ dramatically decreases the amyloid burden in the brains of old APP mice. More importantly, this combination approach significantly ameliorated cognitive deficits in aged APP mice, an outcome unreachable in moderate inhibition of a single secretase. This study is an example of a successful combination therapy that simultaneously affects two targets in the $\mathrm{A} \beta$ production pathway. A study by Wang et al (2011) provides an example of combination therapy simultaneously affecting $\mathrm{A} \beta$ production and clearance pathways.

Successful development of combination therapies for $\mathrm{AD}$ will require significant changes in regulations for clinical trials, which were mainly developed for advancing one drug at a time. There are some developments in the FDA regulations underway that hopefully will provide more flexibility for rapid evaluations of combination regimens involving new targeted agents in a single development program ('codevelopment'; Woodcock et al, 2011). However, it is important to realize that development of combination therapies could introduce additional uncertainty as to the contribution of each component to the treatment efficacy. It will require more vigilant surveillance of a wide range of data sources (preclinical as well as results from initial phases of clinical trials) to monitor efficacy, side effects, and adequacy of biomarkers. Recent examples of clinical trials with semagacestat indicate that regulatory mechanisms are not adequate to ascertain surveillance even for a trial with one drug. Semagacestat failed to demonstrate an intended drug effect in healthy volunteers and instead showed problematic biphasic dynamics of the biomarkers (A $\beta$ in the plasma and the CSF) (Figure 1). These biomarkers were not sufficiently sensitive to reflect the drug effect in $\mathrm{AD}$ patients. In vivo models used during preclinical stages had high sensitivity to the $\mathrm{A} \beta$-lowering effect of the GSI but showed decreased efficacy of the drug in old mice. Despite these problems, the drug was advanced to Phase III clinical trials. 


\section{TAKE-HOME MESSAGE}

Over the past three decades, significant progress has been made in understanding AD. Clinical studies of AD patients and preclinical studies of this disease, including genetically engineered models of $\mathrm{A} \beta$ amyloidosis and tauopathies, have elucidated a number of pathogenic mechanisms, therapeutic targets, and potential mechanism-based treatments. However, in recent years, the first attempts to implement novel treatments based on an understanding of the neurobiology, neuropathology, biochemistry, and genetics of this illness bring rather disappointing results. The amyloid cascade hypothesis served as a foundation for the development of multiple 'A $\beta$ mechanism-based' therapeutics, and their sequential failures in Phase III clinical trials raised bigger and bigger concerns about the validity of the hypothesis. As more data on primary/secondary outcome measures as well as pathology become available, it becomes clear that the reasons behind the failure of these trials were likely an imbalance of side (off target) effects and efficacy, as well as the late initiation of the treatments. In other words, the clinical trials might not be powered enough to prove or reject the amyloid hypothesis. Aside from this somewhat artificially polarized issue, the real lesson from these failures might be that if we do not change the way we translate an original exciting finding into a drug, clinical trials will continue to bring very costly negative results.

In this review, we attempted to illustrate the real challenges of extrapolating preclinical outcomes to clinical trials in humans. To improve predictive validity of the models, preclinical studies should include assessment of whether and how advanced stages of amyloidosis/tau pathologies or advanced age modulate reversibility of cognitive deficits. This will allow for delineating a window of opportunity for each suggested treatment to be effective and to correctly classify candidate treatments as preventative or therapeutic. Particular care should be taken that preclinical studies be sufficiently powered to analyze not only efficacy of a treatment but also its side effects.

Translation of the disease into mouse models might not be the biggest problem. Translation of knowledge between preclinical and different stages of clinical drug development might be an even bigger hurdle. Organization of independent discussion panels that present scientifically sound opinions on expected drug efficacy as well as on mechanisms that potentially limit drug efficacy and mechanisms of side effects would help integrate data from different sources and different stages of drug development to increase the chances of success in Phase III clinical trials. Making the 'pharma-independent' opinions of these discussion panels publicly available before the next anticipated stage of drug development would help influence the otherwise internal 'go-no go' decisions of pharmaceutical companies and prevent spending time and resources on testing questionable compounds.

\section{ACKNOWLEDGEMENTS}

We thank our many colleagues at JHMI and other institutions who have contributed to the original work cited in this review and have engaged us in helpful discussions. We are grateful to Dr A Huberman for careful editing and discussion of the manuscript. Owing to space constrains we were unable to cite all studies relevant to topics discussed. Aspects of this work were supported by grants from the US Public Health Service (NS45150, NS47308, NS41438, NS49088, NS10580, AG05146, AG14248, MH086881, NS047225, and TW008019), as well as the Metropolitan Life Foundation, Adler Foundation, Alzheimer's Association, American Health Assistance Foundation, Rotary CART Fund, Wallace Foundation, Ellison Medical Foundation, and Bristol-Myers Squibb Foundation.

\section{DISCLOSURE}

AVS, TM, TL, PFW, JCT, and PCW declare no conflict of interest. DLP is on the SABs of Biogen Idec and Satori Pharmaceuticals (Cambridge, MA) but does not have current research support from any of the above-mentioned companies. AH has a salary support from MAPP Biopharmaceutical (San Diego, CA).

\section{REFERENCES}

Abramowski D, Wiederhold KH, Furrer U, Jaton AL, Neuenschwander A, Runser MJ et al (2008). Dynamics of Abeta turnover and deposition in different beta-amyloid precursor protein transgenic mouse models following gammasecretase inhibition. J Pharmacol Exp Ther 327: 411-424. Demonstration that in APP mouse models chronic $\gamma$-secretase inhibition lowered amyloid plaque to the extent that is inversely related to the initial amyloid load.

Arendash GW, Gordon MN, Diamond DM, Austin LA, Hatcher JM, Jantzen P et al (2001). Behavioral assessment of Alzheimer's transgenic mice following longterm Abeta vaccination: task specificity and correlations between Abeta deposition and spatial memory. DNA Cell Biol 20: 737-744.

Bartus RT (1979). Physostigmine and recent memory: effects in young and aged nonhuman primates. Science 206: 1087-1089.

Bartus RT, Dean 3rd RL, Beer B, Lippa AS (1982). The cholinergic hypothesis of geriatric memory dysfunction. Science 217: 408-414.

Bateman RJ, Siemers ER, Mawuenyega KG, Wen G, Browning KR, Sigurdson WC et al (2009). A gamma-secretase inhibitor decreases amyloid-beta production in the central nervous system. Ann Neurol 66: 48-54. The demonstration of biphasic response of CSF $A \beta$ to acute treatment with semagasestat in healthy volunteers.

Beach TG, Walker DG, Potter PE, Sue LI, Fisher A (2001). Reduction of cerebrospinal fluid amyloid beta after systemic administration of M1 muscarinic agonists. Brain Res 905: 220-223.

Bertram L, Tanzi RE (2009). Genome-wide association studies in Alzheimer's disease. Hum Mol Genet 18: R137-R145.

Birks J (2006). Cholinesterase inhibitors for Alzheimer's disease. Cochrane Database Syst Rev(1): CD005593.

Black W, Almeida OP (2004). A systematic review of the association between the behavioral and psychological symptoms of dementia and burden of care. Int Psychogeriatr 16: 295-315.

Boche D, Denham N, Holmes C, Nicoll JA (2010). Neuropathology after active Abeta42 immunotherapy: implications for Alzheimer's disease pathogenesis. Acta Neuropathol 120: 369-384. Clinical and neuropathological follow up of $A D$ patients in the initial AN1792 immunization trial demonstrating that plaques had been removed but here was no evidence of a beneficial effect on synapses.

Borchelt DR, Ratovitski T, van Lare J, Lee MK, Gonzales V, Jenkins NA et al (1997). Accelerated amyloid deposition in the brains of transgenic mice coexpressing mutant presenilin 1 and amyloid precursor proteins. Neuron 19: 939-945. 
Bowen DM, Smith CB, White P, Davison AN (1976). Neurotransmitter-related enzymes and indices of hypoxia in senile dementia and other abiotrophies. Brain 99: 459-496.

Braak H, Braak E (1991). Neuropathological stageing of Alzheimer-related changes. Acta Neuropathol 82: 239-259.

Brousseau G, Rourke BP, Burke B (2007). Acetylcholinesterase inhibitors, neuropsychiatric symptoms, and Alzheimer's disease subtypes: an alternate hypothesis to global cognitive enhancement. Exp Clin Psychopharmacol 15: 546-554.

Brunden KR, Trojanowski JQ, Lee VM (2008). Evidence that non-fibrillar tau causes pathology linked to neurodegeneration and behavioral impairments. J Alzheimers Dis 14: 393-399.

Burton CR, Meredith JE, Barten DM, Goldstein ME, Krause CM, Kieras CJ et al (2008). The amyloid-beta rise and gamma-secretase inhibitor potency depend on the level of substrate expression. J Biol Chem 283: 22992-23003. Recent overview of an 'A $\boldsymbol{\beta}$ rise'phenomenon (an increase in the $A \boldsymbol{\beta}$ secretion after gamma-secretase inhibitors). The Abeta rise and potency shift are discussed as relevant factors in the development of gamma-secretase inhibitors.

Buttini M, Masliah E, Barbour R, Grajeda H, Motter R, Johnson-Wood K et al (2005). Beta-amyloid immunotherapy prevents synaptic degeneration in a mouse model of Alzheimer's disease. J Neurosci 25: 9096-9101.

Caccamo A, Oddo S, Billings LM, Green KN, Martinez-Coria H, Fisher A et al (2006). M1 receptors play a central role in modulating AD-like pathology in transgenic mice. Neuron 49: 671-682.

Cai H, Wang Y, McCarthy D, Wen H, Borchelt DR, Price DL et al (2001). BACE1 is the major beta-secretase for generation of Abeta peptides by neurons. Nat Neurosci 4: 233-234.

Cappell J, Herrmann N, Cornish S, Lanctot KL (2010). The pharmacoeconomics of cognitive enhancers in moderate to severe Alzheimer's disease. CNS Drugs 24: 909-927.

Caughey B, Lansbury PT (2003). Protofibrils, pores, fibrils, and neurodegeneration: separating the responsible protein aggregates from the innocent bystanders. Annu Rev Neurosci 26: 267-298.

Chang WP, Huang X, Downs D, Cirrito JR, Koelsch G, Holtzman DM et al (2011). Beta-secretase inhibitor GRL-8234 rescues age-related cognitive decline in APP transgenic mice. FASEB J 25: 775-784.

Chang WP, Koelsch G, Wong S, Downs D, Da H, Weerasena V et al (2004). In vivo inhibition of Abeta production by memapsin 2 (beta-secretase) inhibitors. J Neurochem 89: 1409-1416.

Chen G, Chen KS, Knox J, Inglis J, Bernard A, Martin SJ et al (2000). A learning deficit related to age and beta-amyloid plaques in a mouse model of Alzheimer's disease. Nature 408: 975-979.

Chen G, Chen KS, Kobayashi D, Barbour R, Motter R, Games D et al (2007). Active beta-amyloid immunization restores spatial learning in PDAPP mice displaying very low levels of beta-amyloid. J Neurosci 27: 2654-2662. Demonstration of decreased efficacy of anti-A $\boldsymbol{\beta}$ immunization in a mouse model of amyloidosis of advanced age.

Chow WW, Savonenko AV, Melnikova T, Kim H, Price DL, Li Tet al (2010). Modeling an anti-amyloid combination therapy for Alzheimer's disease. Sci Trans/ Med 2 13ra11. The first in vivo evidence that mild inhibition of two targets in the A $\beta$ production pathway overcomes the limitations of a treatment affecting single target.

Citron M (2002). Emerging Alzheimer's disease therapies: inhibition of betasecretase. Neurobiol Aging 23: 1017-1022.

Citron M (2010). Alzheimer's disease: strategies for disease modification. Nat Rev Drug Discov 9: 387-398.

Citron M, Diehl TS, Gordon G, Biere AL, Seubert P, Selkoe DJ (1996). Evidence that the 42- and 40-amino acid forms of amyloid beta protein are generated from the beta-amyloid precursor protein by different protease activities. Proc Natl Acad Sci USA 93: 13170-13175.

Citron M, Oltersdorf T, Haass C, McConlogue L, Hung AY, Seubert P et al (1992). Mutation of the beta-amyloid precursor protein in familial Alzheimer's disease increases beta-protein production. Nature 360: 672-674.

Coyle JT, Price DL, DeLong MR (1983). Alzheimer's disease: a disorder of cortical cholinergic innervation. Science 219: 1184-1190.

Cummings JL (2004). Treatment of Alzheimer's disease: current and future therapeutic approaches. Rev Neurol Dis 1: 60-69.

Das P, Chapoval S, Howard V, David CS, Golde TE (2003). Immune responses against Abeta1-42 in HLA class II transgenic mice: implications for Abeta1-42 immune-mediated therapies. Neurobiol Aging 24: 969-976.

Das P, Murphy MP, Younkin LH, Younkin SG, Golde TE (2001). Reduced effectiveness of Abeta1-42 immunization in APP transgenic mice with significant amyloid deposition. Neurobiol Aging 22: 721-727.

Davies P, Maloney AJ (1976). Selective loss of central cholinergic neurons in Alzheimer's disease. Lancet 2: 1403.
Davis KL, Mohs RC, Marin D, Purohit DP, Perl DP, Lantz M et al (1999). Cholinergic markers in elderly patients with early signs of Alzheimer disease. JAMA 281 1401-1406.

Davis KL, Mohs RC, Tinklenberg JR (1979). Enhancement of memory by physostigmine. N Engl J Med 301: 946.

Davis KL, Mohs RC, Tinklenberg JR, Pfefferbaum A, Hollister LE, Kopell BS (1978). Physostigmine: improvement of long-term memory processes in normal humans Science 201: 272-274

De Strooper B (2003). Aph-1, Pen-2, and Nicastrin with Presenilin generate an active gamma-Secretase complex. Neuron 38: 9-12.

De Strooper B, Vassar R, Golde T (2010). The secretases: enzymes with therapeutic potential in Alzheimer disease. Nat Rev Neurol 6: 99-107.

DeKosky ST, Ikonomovic MD, Styren SD, Beckett L, Wisniewski S, Bennett DA et al (2002). Upregulation of choline acetyltransferase activity in hippocampus and frontal cortex of elderly subjects with mild cognitive impairment. Ann Neurol 51 145-155.

DeMattos RB, Bales KR, Cummins DJ, Paul SM, Holtzman DM (2002). Brain to plasma amyloid-beta efflux: a measure of brain amyloid burden in a mouse model of Alzheimer's disease. Science 295: 2264-2267.

DeMattos RB, Cirrito JR, Parsadanian M, May PC, O'Dell MA, Taylor JW et al (2004). ApoE and clusterin cooperatively suppress Abeta levels and deposition: evidence that ApoE regulates extracellular Abeta metabolism in vivo. Neuron 41: 193-202.

Digby GJ, Shirey JK, Conn PJ (2010). Allosteric activators of muscarinic receptors as novel approaches for treatment of CNS disorders. Mol Biosyst 6: 1345-1354

Dodart JC, Bales KR, Gannon KS, Greene SJ, DeMattos RB, Mathis C et al (2002). Immunization reverses memory deficits without reducing brain Abeta burden in Alzheimer's disease model. Nat Neurosci 5: 452-457. The first evidence of an acute rescue of cognitinve deficits after a passive transfer of anti-A $\beta$ antibodies in a mouse model of amyloidosis.

Eriksen JL, Janus CG (2007). Plaques, tangles, and memory loss in mouse models of neurodegeneration. Behav Genet 37: 79-100.

Falls DL (2003). Neuregulins: functions, forms, and signaling strategies. Exp Cell Res 284: 14-30.

Fisher A (2007). M1 muscarinic agonists target major hallmarks of Alzheimer's disease-an update. Curr Alzheimer Res 4: 577-580.

Francis PT, Nordberg A, Arnold SE (2005). A preclinical view of cholinesterase inhibitors in neuroprotection: do they provide more than symptomatic benefits in Alzheimer's disease? Trends Pharmacol Sci 26: 104-111.

Fukumoto H, Takahashi H, Tarui N, Matsui J, Tomita T, Hirode M et al (2010). A noncompetitive BACE1 inhibitor TAK-070 ameliorates Abeta pathology and behavioral deficits in a mouse model of Alzheimer's disease. J Neurosci 30: 11157-11166.

Gauthier S, Loft H, Cummings J (2008). Improvement in behavioural symptoms in patients with moderate to severe Alzheimer's disease by memantine: a pooled data analysis. Int J Geriatr Psychiatry 23: 537-545.

German DC, Manaye KF, White 3rd CL, Woodward DJ, Mclntire DD, Smith WK et al (1992). Disease-specific patterns of locus coeruleus cell loss. Ann Neurol 32 667-676.

Ghosh AK, Gemma S, Tang J (2008). beta-Secretase as a therapeutic target for Alzheimer's disease. Neurotherapeutics 5: 399-408.

Giannakopoulos P, Herrmann FR, Bussiere T, Bouras C, Kovari E, Perl DP et al (2003). Tangle and neuron numbers, but not amyloid load, predict cognitive status in Alzheimer's disease. Neurology 60: 1495-1500. One of the neuropathological studies demonstrating lack of correlations between dementia and $A \beta$ plaque load in the brain of $A D$ patients.

Gilman S, Koller M, Black RS, Jenkins L, Griffith SG, Fox NC et al (2005). Clinica effects of Abeta immunization (AN1792) in patients with AD in an interrupted trial. Neurology 64: 1553-1562.

Gilmor ML, Erickson JD, Varoqui H, Hersh LB, Bennett DA, Cochran EJ et al (1999). Preservation of nucleus basalis neurons containing choline acetyltransferase and the vesicular acetylcholine transporter in the elderly with mild cognitive impairment and early Alzheimer's disease. J Comp Neurol 411: 693-704.

Golde TE, Schneider LS, Koo EH (2011). Anti-abeta therapeutics in Alzheimer's disease: the need for a paradigm shift. Neuron 69: 203-213. A recent update on revisions of amyloid cascade hypothesis of $A D$

Gordon MN, King DL, Diamond DM, Jantzen PT, Boyett KV, Hope CE et al (2001). Correlation between cognitive deficits and Abeta deposits in transgenic APP+PS1 mice. Neurobiol Aging 22: 377-385.

Gotz J, Chen F, van Dorpe J, Nitsch RM (2001). Formation of neurofibrillary tangles in P301I tau transgenic mice induced by Abeta 42 fibrils. Science 293: 1491-1495.

Haass C (2002). New hope for Alzheimer disease vaccine. Nat Med 8: 1195-1196. Clear outline of differences between the antibodies produced as a result of anti-A $\beta$ active immunization in $A D$ patients and mouse models of $A D$. 
Hadland BK, Manley NR, Su D, Longmore GD, Moore CL, Wolfe MS et al (2001). Gamma -secretase inhibitors repress thymocyte development. Proc Natl Acad Sci USA 98: 7487-7491.

Hardy J (1996). New insights into the genetics of Alzheimer's disease. Ann Med 28: 255-258.

Hardy JA, Higgins GA (1992). Alzheimer's disease: the amyloid cascade hypothesis. Science 256: 184-185.

He G, Luo W, Li P, Remmers C, Netzer WJ, Hendrick J et al (2010). Gammasecretase activating protein is a therapeutic target for Alzheimer's disease. Nature 467: 95-98.

Henley DB, May PC, Dean RA, Siemers ER (2009). Development of semagacestat (LY450139), a functional gamma-secretase inhibitor, for the treatment of Alzheimer's disease. Expert Opin Pharmacother 10: 1657-1664.

Herrup K (2010). Reimagining Alzheimer's disease-an age-based hypothesis. J Neurosci 30: 16755-16762. A recent update on revisions of amyloid cascade hypothesis of $A D$

Hock C, Konietzko U, Papassotiropoulos A, Wollmer A, Streffer J, von Rotz RC et al (2002). Generation of antibodies specific for beta-amyloid by vaccination of patients with Alzheimer disease. Nat Med 8: 1270-1275.

Hock C, Konietzko U, Streffer JR, Tracy J, Signorell A, Muller-Tillmanns B et al (2003). Antibodies against beta-amyloid slow cognitive decline in Alzheimer's disease. Neuron 38: 547-554.

Holmes C, Boche D, Wilkinson D, Yadegarfar G, Hopkins V, Bayer A et al (2008). Long-term effects of Abeta42 immunisation in Alzheimer's disease: follow-up of a randomised, placebo-controlled phase I trial. Lancet 372: 216-223. Demonstration that although immunization with $A \beta(42)$ resulted in clearance of amyloid plaques in patients with Alzheimer's disease, this clearance did not prevent progressive neurodegeneration.

$\mathrm{Hu}$ X, Hicks CW, He W, Wong P, Macklin WB, Trapp BD et al (2006). Bace1 modulates myelination in the central and peripheral nervous system. Nat Neurosci 9: 1520-1525.

Jankowsky JL, Savonenko A, Schilling G, Wang J, Xu G, Borchelt DR (2002). Transgenic mouse models of neurodegenerative disease: opportunities for therapeutic development. Curr Neurol Neurosci Rep 2: 457-464.

Janus C, Pearson J, McLaurin J, Mathews PM, Jiang Y, Schmidt SD et al (2000). A beta peptide immunization reduces behavioural impairment and plaques in a model of Alzheimer's disease. Nature 408: 979-982.

Jaworski T, Dewachter I, Seymour CM, Borghgraef $\mathrm{P}$, Devijver $\mathrm{H}$, Kugler $\mathrm{S}$ et al (2010). Alzheimer's disease: old problem, new views from transgenic and viral models. Biochim Biophys Acta 1802: 808-818.

Kamenetz F, Tomita T, Hsieh H, Seabrook G, Borchelt D, Iwatsubo T et al (2003). APP processing and synaptic function. Neuron 37: 925-937. Evidence that A $\boldsymbol{\beta}$ selectively depresses excitatory synaptic transmission onto neurons in activity-dependent manner and that endogenous $\mathbf{A} \boldsymbol{\beta}$ production may normally participate in a negative feedback keeping neuronal hyperactivity in check.

Kayed R, Head E, Sarsoza F, Saing T, Cotman CW, Necula M et al (2007). Fibril specific, conformation dependent antibodies recognize a generic epitope common to amyloid fibrils and fibrillar oligomers that is absent in prefibrillar oligomers. Mol Neurodegener 2: 18.

Kayed R, Head E, Thompson JL, Mclntire TM, Milton SC, Cotman CW et al (2003). Common structure of soluble amyloid oligomers implies common mechanism of pathogenesis. Science 300: 486-489.

Kenton L, Boon F, Cain DP (2008). Combined but not individual administration of beta-adrenergic and serotonergic antagonists impairs water maze acquisition in the rat. Neuropsychopharmacology 33: 1298-1311.

Kim S, Swaminathan S, Shen L, Risacher SL, Nho K, Foroud T et al (2011). Genome-wide association study of CSF biomarkers Abeta1-42, t-tau, and p-tau181p in the ADNI cohort. Neurology 76: 69-79.

Kitazume S, Tachida Y, Oka R, Shirotani K, Saido TC, Hashimoto Y (2001). Alzheimer's beta-secretase, beta-site amyloid precursor protein-cleaving enzyme, is responsible for cleavage secretion of a Golgi-resident sialyltransferase. Proc Natl Acad Sci USA 98: 13554-13559.

Klegeris A, McGeer EG, McGeer PL (2007). Therapeutic approaches to inflammation in neurodegenerative disease. Curr Opin Neurol 20: 351-357.

Kotilinek LA, Bacskai B, Westerman M, Kawarabayashi T, Younkin L, Hyman BT et al (2002). Reversible memory loss in a mouse transgenic model of Alzheimer's disease. J Neurosci 22: 6331-6335.

Kuperstein I, Broersen K, Benilova I, Rozenski J, Jonckheere W, Debulpaep M et al (2010). Neurotoxicity of Alzheimer's disease Abeta peptides is induced by small changes in the Abeta42 to Abeta40 ratio. EMBO J 29: 3408-3420.

Laird FM, Cai H, Savonenko AV, Farah MH, He K, Melnikova Tet al (2005). BACE1, a major determinant of selective vulnerability of the brain to amyloid-beta amyloidogenesis, is essential for cognitive, emotional, and synaptic functions. J Neurosci 25: 11693-11709.
Lanctot KL, Herrmann N, LouLou MM (2003a). Correlates of response to acetylcholinesterase inhibitor therapy in Alzheimer's disease. J Psychiatry Neurosci 28: 13-26.

Lanctot KL, Herrmann N, Yau KK, Khan LR, Liu BA, LouLou MM et al (2003b). Efficacy and safety of cholinesterase inhibitors in Alzheimer's disease: a metaanalysis. CMAJ 169: 557-564.

Lanz TA, Himes CS, Pallante G, Adams L, Yamazaki S, Amore B et al (2003). The gamma-secretase inhibitor $\mathrm{N}$-[N-(3,5-difluorophenacetyl)-L-alanyl]-S-phenylglycine t-butyl ester reduces $\mathrm{A}$ beta levels in vivo in plasma and cerebrospinal fluid in young (plaque-free) and aged (plaque-bearing) Tg2576 mice. J Pharmacol Exp Ther 305: 864-871

Lanz TA, Karmilowicz MJ, Wood KM, Pozdnyakov N, Du P, Piotrowski MA et al (2006). Concentration-dependent modulation of amyloid-beta in vivo and in vitro using the gamma-secretase inhibitor, LY-450139. J Pharmacol Exp Ther 319: 924-933.

Lee EB, Leng LZ, Lee VM, Trojanowski JQ (2005). Meningoencephalitis associated with passive immunization of a transgenic murine model of Alzheimer's amyloidosis. FEBS Lett 579: 2564-2568.

Lee EB, Leng LZ, Zhang B, Kwong L, Trojanowski JQ, Abel T et al (2006). Targeting amyloid-beta peptide (Abeta) oligomers by passive immunization with a conformation-selective monoclonal antibody improves learning and memory in Abeta precursor protein (APP) transgenic mice. J Biol Chem 281: 4292-4299.

Lee VM, Goedert M, Trojanowski JQ (2001). Neurodegenerative tauopathies. Annu Rev Neurosci 24: 1121-1159.

Lemere CA, Masliah E (2010). Can Alzheimer disease be prevented by amyloid-beta immunotherapy? Nat Rev Neurol 6: 108-119.

Lesne S, Kotilinek L, Ashe KH (2008). Plaque-bearing mice with reduced levels of oligomeric amyloid-beta assemblies have intact memory function. Neuroscience 151: $745-749$.

Lewis J, Dickson DW, Lin WL, Chisholm L, Corral A, Jones G et al (2001). Enhanced neurofibrillary degeneration in transgenic mice expressing mutant tau and APP. Science 293: 1487-1491

Li Q, Sudhof TC (2004). Cleavage of amyloid-beta precursor protein and amyloidbeta precursor-like protein by BACE 1. J Biol Chem 279: 10542-10550.

Li T, Wen H, Brayton C, Laird FM, Ma G, Peng S et al (2007). Moderate reduction of gamma-secretase attenuates amyloid burden and limits mechanism-based liabilities. J Neurosci 27: 10849-10859.

Lipton SA (2005). The molecular basis of memantine action in Alzheimer's disease and other neurologic disorders: low-affinity, uncompetitive antagonism. Curr Alzheimer Res 2: 155-165.

Liu Y, Yoo MJ, Savonenko A, Stirling W, Price DL, Borchelt DR et al (2008). Amyloid pathology is associated with progressive monoaminergic neurodegeneration in a transgenic mouse model of Alzheimer's disease. J Neurosci 28: 13805-13814.

Lopez OL, Becker JT, Wahed AS, Saxton J, Sweet RA, Wolk DA et al (2009). Longterm effects of the concomitant use of memantine with cholinesterase inhibition in Alzheimer disease. J Neurol Neurosurg Psychiatry 80: 600-607.

Luo Y, Bolon B, Kahn S, Bennett BD, Babu-Khan S, Denis P et al (2001). Mice deficient in BACE1, the Alzheimer's beta-secretase, have normal phenotype and abolished beta-amyloid generation. Nat Neurosci 4: 231-232.

Marcyniuk B, Mann DM, Yates PO (1986). The topography of cell loss from locus coeruleus in Alzheimer's disease. J Neurol Sci 76: 335-345.

May PC, Yang Z, Li W, Hyslop PA, Siemers ER, Boggs L (2004). Multicompartmental pharmaco-dynamic assessment of teh functional gammasecretase inhibitor LY450139 in PDAPP transgenic mice and non-transgenic mice. Neurobiol Aging S 1: S65.

McArthur B, Borsini F (2008). Animal and Translational Models for CNS Drug Discovery: Psychiatric Disorders, vol 1. Elsevier. p 528.

McEver RP, Cummings RD (1997). Role of PSGL-1 binding to selectins in leukocyte recruitment. J Clin Invest 100: S97-103.

McGowan E, Eriksen J, Hutton M (2006). A decade of modeling Alzheimer's disease in transgenic mice. Trends Genet 22: 281-289.

McLaurin J, Cecal R, Kierstead ME, Tian X. Phinney AL, Manea M et al (2002). Therapeutically effective antibodies against amyloid-beta peptide target amyloid-beta residues 4-10 and inhibit cytotoxicity and fibrillogenesis. Nat Med 8: 1263-1269.

Mecocci P, Bladstrom A, Stender K (2009). Effects of memantine on cognition in patients with moderate to severe Alzheimer's disease: post-hoc analyses of ADAS-cog and SIB total and single-item scores from six randomized, double-blind, placebo-controlled studies. Int J Geriatr Psychiatry 24: 532-538

Michailov GV, Sereda MW, Brinkmann BG, Fischer TM, Haug B, Birchmeier C et al (2004). Axonal neuregulin-1 regulates myelin sheath thickness. Science 304 : $700-703$ 
Monsonego A, Imitola J, Petrovic S, Zota V, Nemirovsky A, Baron R et al (2006). Abeta-induced meningoencephalitis is IFN-gamma-dependent and is associated with $\mathrm{T}$ cell-dependent clearance of Abeta in a mouse model of Alzheimer's disease. Proc Natl Acad Sci USA 103: 5048-5053.

Morgan D, Diamond DM, Gottschall PE, Ugen KE, Dickey C, Hardy J et al (2000). A beta peptide vaccination prevents memory loss in an animal model of Alzheimer's disease. Nature 408: 982-985.

Naslund J, Haroutunian V, Mohs R, Davis KL, Davies P, Greengard P et al (2000). Correlation between elevated levels of amyloid beta-peptide in the brain and cognitive decline. JAMA 283: 1571-1577.

Nicolas M, Wolfer A, Raj K, Kummer JA, Mill P, van Noort M et al (2003). Notch1 functions as a tumor suppressor in mouse skin. Nat Genet 33: 416-421.

Nicoll JA, Wilkinson D, Holmes C, Steart P, Markham H, Weller RO (2003). Neuropathology of human Alzheimer disease after immunization with amyloid beta peptide: a case report. Nat Med 9: 448-452.

O'Brien JT, Burns A (2010). Clinical practice with anti-dementia drugs: a revised (second) consensus statement from the British Association for Psychopharmacology. J Psychopharmacol.

O'Nuallain B, Wetzel R (2002). Conformational Abs recognizing a generic amyloid fibril epitope. Proc Natl Acad Sci USA 99: 1485-1490.

Oddo S, Caccamo A, Shepherd JD, Murphy MP, Golde TE, Kayed R et al (2003). Triple-transgenic model of Alzheimer's disease with plaques and tangles: intracellular Abeta and synaptic dysfunction. Neuron 39: 409-421. The first report showing that in 3xTG AD mice soluble tau also plays a role in the cognitive decline in the presence of concomitant $A \beta$ pathology.

Oddo S, LaFerla FM (2006). The role of nicotinic acetylcholine receptors in Alzheimer's disease. J Physiol Paris 99: 172-179.

Oddo S, Vasilevko V, Caccamo A, Kitazawa M, Cribbs DH, LaFerla FM (2006). Reduction of soluble Abeta and tau, but not soluble Abeta alone, ameliorates cognitive decline in transgenic mice with plaques and tangles. J Biol Chem 281 39413-39423.

Ohno M, Sametsky EA, Younkin LH, Oakley H, Younkin SG, Citron M et al (2004). BACE1 deficiency rescues memory deficits and cholinergic dysfunction in a mouse model of Alzheimer's disease. Neuron 41: 27-33.

Okun I, Tkachenko SE, Khvat A, Mitkin O, Kazey V, Ivachtchenko AV (2010). From anti-allergic to anti-Alzheimer's: molecular pharmacology of Dimebon. Curr Alzheimer Res 7: 97-112.

Olton DS, Feustle WA (1981). Hippocampal function required for nonspatial working memory. Exp Brain Res 41: 380-389.

Orgogozo JM, Gilman S, Dartigues JF, Laurent B, Puel M, Kirby LC et al (2003). Subacute meningoencephalitis in a subset of patients with $A D$ after Abeta42 immunization. Neurology 61: 46-54.

Parvizi J, Van Hoesen GW, Damasio A (2001). The selective vulnerability of brainstem nuclei to Alzheimer's disease. Ann Neurol 49: 53-66.

Pastorino L, Ikin AF, Lamprianou S, Vacaresse N, Revelli JP, Platt K et al (2004). BACE (beta-secretase) modulates the processing of APLP2 in vivo. $\mathrm{Mol}$ Cell Neurosci 25: 642-649.

Perry EK, Tomlinson BE, Blessed G, Bergmann K, Gibson PH, Perry RH (1978). Correlation of cholinergic abnormalities with senile plaques and mental test scores in senile dementia. Br Med J 2: 1457-1459.

Perry VH, Nicoll JA, Holmes C (2010). Microglia in neurodegenerative disease. Nat Rev Neurol 6: 193-201.

Pfeifer M, Boncristiano S, Bondolfi L, Stalder A, Deller T, Staufenbiel M et al (2002). Cerebral hemorrhage after passive anti-Abeta immunotherapy. Science 298: 1379. First report about cerebral hemorrhages as a possible side effect of a passive transfer of anti-A $\beta$ antibodies in a mouse model of $A D$.

Pimplikar SW, Nixon RA, Robakis NK, Shen J, Tsai LH (2010). Amyloid-independent mechanisms in Alzheimer's disease pathogenesis. J Neurosci 30: 14946-14954.

Pinto T, Lanctot KL, Herrmann N (2011). Revisiting the cholinergic hypothesis of behavioral and psychological symptoms in dementia of the Alzheimer's type. Ageing Res Rev 10: 404-412.

Porsteinsson AP, Grossberg GT, Mintzer J, Olin JT (2008). Memantine treatment in patients with mild to moderate Alzheimer's disease already receiving a cholinesterase inhibitor: a randomized, double-blind, placebo-controlled trial. Curr Alzheimer Res 5: 83-89.

Portelius E, Dean RA, Gustavsson MK, Andreasson U, Zetterberg H, Siemers E et al (2010). A novel Abeta isoform pattern in CSF reflects gamma-secretase inhibition in Alzheimer disease. Alzheimers Res Ther 2: 7. Demonstration that A $\mathbf{\beta 1 - 4 0}$ and Aß1-42 is not sensitive biomarker to central effects of a $\gamma$-secretase inhibitor Semagasestat.

Price D, Martin L, Savonenko A, Li T, Laird F, Wong P (2007). Selected Genetically Engineered Models Relevant to Human Neurodegenerative Disease. In: Rosenberg RN, Di Mauro S, Paulson H, Ptacek L and Nestler E (eds). The Molecular and Genetic Basis of Neurological and Psychiatric Disease. Lippincott Williams \& Wilkins. pp. 35-62.
Price DL, Tanzi RE, Borchelt DR, Sisodia SS (1998). Alzheimer's disease: genetic studies and transgenic models. Annu Rev Genet 32: 461-493.

Racke MM, Boone LI, Hepburn DL, Parsadainian M, Bryan MT, Ness DK et al (2005). Exacerbation of cerebral amyloid angiopathy-associated microhemorrhage in amyloid precursor protein transgenic mice by immunotherapy is dependent on antibody recognition of deposited forms of amyloid beta. $J$ Neurosci 25: 629-636.

Reisberg B, Doody R, Stoffler A, Schmitt F, Ferris S, Mobius HJ (2003). Memantine in moderate-to-severe Alzheimer's disease. N Engl J Med 348: 1333-1341.

Rizzo P, Osipo C, Foreman K, Golde T, Osborne B, Miele L (2008). Rational targeting of Notch signaling in cancer. Oncogene 27: 5124-5131.

Roberds SL, Anderson J, Basi G, Bienkowski MJ, Branstetter DG, Chen KS et al (2001). BACE knockout mice are healthy despite lacking the primary betasecretase activity in brain: implications for Alzheimer's disease therapeutics. Hum Mol Genet 10: 1317-1324.

Roberson ED, Scearce-Levie K, Palop JJ, Yan F, Cheng IH, Wu T et al (2007). Reducing endogenous tau ameliorates amyloid beta-induced deficits in an Alzheimer's disease mouse model. Science 316: 750-754.

Rogers SL, Doody RS, Mohs RC, Friedhoff LT (1998). Donepezil improves cognition and global function in Alzheimer disease: a 15-week, double-blind, placebocontrolled study. Donepezil Study Group. Arch Intern Med 158: 1021-1031.

Rossor MN, Iversen LL, Mountjoy CQ, Roth M, Hawthorn J, Ang VY et al (1980). Arginine vasopressin and choline acetyltransferase in brains of patients with Alzheimer type senile dementia. Lancet 2: 1367-1368.

Sabbagh M, Cummings J (2011). Progressive cholinergic decline in Alzheimer's Disease: consideration for treatment with donepezil $23 \mathrm{mg}$ in patients with moderate to severe symptomatology. BMC Neurol 11: 21

Saito T, Iwata N, Tsubuki S, Takaki Y, Takano J, Huang SM et al (2005). Somatostatin regulates brain amyloid beta peptide Abeta42 through modulation of proteolytic degradation. Nat Med 11: 434-439.

Salloway S, Sperling R, Gilman S, Fox NC, Blennow K, Raskind M et al (2009). A phase 2 multiple ascending dose trial of bapineuzumab in mild to moderate Alzheimer disease. Neurology 73: 2061-2070.

Sankaranarayanan S, Price EA, Wu G, Crouthamel MC, Shi XP, Tugusheva K et al (2008). In vivo beta-secretase 1 inhibition leads to brain Abeta lowering and increased alpha-secretase processing of amyloid precursor protein without effect on neuregulin-1. J Pharmacol Exp Ther 324: 957-969.

Santacruz K, Lewis J, Spires T, Paulson J, Kotilinek L, Ingelsson M et al (2005). Tau suppression in a neurodegenerative mouse model improves memory function. Science 309: 476-481.

Savonenko A, Laird F, Troncoso J, Wong P, Price D (2005a). Role of Alzheimer's disease models in designing and testing experimental therapeutics. Drug Discov Today 2: 305-312.

Savonenko A, Xu GM, Melnikova T, Morton JL, Gonzales V, Wong MP et al (2005b). Episodic-like memory deficits in the APPswe/PS1dE9 mouse model of Alzheimer's disease: relationships to beta-amyloid deposition and neurotransmitter abnormalities. Neurobiol Dis 18: 602-617.

Savonenko AV, Borchelt DL (2008). Transgenic mouse models of Alzheimer's disease and episodic memory. In: Dere E, Easton A, Nadel L and Huston JP(eds). Handbook of Episodic Memory. Elsevier. pp. 553-573.

Savonenko AV, Melnikova T, Laird FM, Stewart KA, Price DL, Wong PC (2008). Alteration of BACE1-dependent NRG1/ErbB4 signaling and schizophrenia-like phenotypes in BACE1-null mice. Proc Natl Acad Sci USA 105 5585-5590.

Schenk D, Barbour R, Dunn W, Gordon G, Grajeda H, Guido T et al (1999). Immunization with amyloid-beta attenuates Alzheimer-disease-like pathology in the PDAPP mouse. Nature 400: 173-177. The first report that active immunization approach can ameliorate amyoid burden in brains of mice with $A \boldsymbol{\beta}$ amyloidosis

Schneider A, Mandelkow E (2008). Tau-based treatment strategies in neurodegenerative diseases. Neurotherapeutics 5: 443-457.

Schneider LS, Insel PS, Weiner MW (2011). Treatment with cholinesterase inhibitors and memantine of patients in the Alzheimer's Disease Neuroimaging Initiative. Arch Neurol 68: 58-66.

Selkoe DJ, Schenk D (2003). Alzheimer's disease: molecular understanding predicts amyloid-based therapeutics. Annu Rev Pharmacol Toxicol 43: 545-584.

Senior K (2002). Dosing in phase II trial of Alzheimer's vaccine suspended. Lancet Neurol 1: 3

Sherrington R, Rogaev El, Liang Y, Rogaeva EA, Levesque G, Ikeda M et al (1995). Cloning of a gene bearing missense mutations in early-onset familial Alzheimer's disease. Nature 375: 754-760.

Shimohama S, Kihara T (2001). Nicotinic receptor-mediated protection against beta-amyloid neurotoxicity. Biol Psychiatry 49: 233-239.

Siemers E, Skinner M, Dean RA, Gonzales C, Satterwhite J, Farlow M et al (2005). Safety, tolerability, and changes in amyloid beta concentrations after 
administration of a gamma-secretase inhibitor in volunteers. Clin Neuropharmacol 28: 126-132. The demonstration of biphasic response of plasma A $\beta$ to acute treatment with semagasestat in healthy volunteers.

Siemers ER, Friedrich S, Dean RA, Gonzales CR, Farlow MR, Paul SM et al (2010). Safety and changes in plasma and cerebrospinal fluid amyloid beta after a single administration of an amyloid beta monoclonal antibody in subjects with Alzheimer disease. Clin Neuropharmacol 33: 67-73.

Sigurdsson EM, Knudsen E, Asuni A, Fitzer-Attas C, Sage D, Quartermain D et al (2004). An attenuated immune response is sufficient to enhance cognition in an Alzheimer's disease mouse model immunized with amyloid-beta derivatives. $J$ Neurosci 24: 6277-6282.

Spooner ET, Desai RV, Mori C, Leverone JF, Lemere CA (2002). The generation and characterization of potentially therapeutic Abeta antibodies in mice: differences according to strain and immunization protocol. Vaccine 21: 290-297.

Stefansson H, Sigurdsson E, Steinthorsdottir V, Bjornsdottir S, Sigmundsson T, Ghosh S et al (2002). Neuregulin 1 and susceptibility to schizophrenia. Am J Hum Genet 71: 877-892.

Tariot PN, Farlow MR, Grossberg GT, Graham SM, McDonald S, Gergel I (2004). Memantine treatment in patients with moderate to severe Alzheimer disease already receiving donepezil: a randomized controlled trial. JAMA 291: 317-324.

Tomic JL, Pensalfini A, Head E, Glabe CG (2009). Soluble fibrillar oligomer levels are elevated in Alzheimer's disease brain and correlate with cognitive dysfunction. Neurobiol Dis 35: 352-358. Demonstration that the levels of fibrillar oligomers significantly correlate with cognitive decline (MMSE scores) as well as the neuropathological hallmarks of $A D$

van Es JH, van Gijn ME, Riccio O, van den Born M, Vooijs M, Begthel H et al (2005). Notch/gamma-secretase inhibition turns proliferative cells in intestinal crypts and adenomas into goblet cells. Nature 435: 959-963.

Vassar R (2002). Beta-secretase (BACE) as a drug target for Alzheimer's disease. Adv Drug Deliv Rev 54: 1589-1602.

Vassar R, Kovacs DM, Yan R, Wong PC (2009). The beta-secretase enzyme BACE in health and Alzheimer's disease: regulation, cell biology, function, and therapeutic potential. J Neurosci 29: 12787-12794.

von Arnim CA, Kinoshita A, Peltan ID, Tangredi MM, Herl L, Lee BM et al (2005). The low density lipoprotein receptor-related protein (LRP) is a novel beta-secretase (BACE1) substrate. J Biol Chem 280: 17777-17785.

Voytko ML, Olton DS, Richardson RT, Gorman LK, Tobin JR, Price DL (1994). Basal forebrain lesions in monkeys disrupt attention but not learning and memory. J Neurosci 14: 167-186.

Walsh DM, Klyubin I, Fadeeva JV, Cullen WK, Anwyl R, Wolfe MS et al (2002). Naturally secreted oligomers of amyloid beta protein potently inhibit hippocampal long-term potentiation in vivo. Nature 416: 535-539.
Wang A, Das P, Switzer 3rd RC, Golde TE, Jankowsky JL (2011). Robust amyloid clearance in a mouse model of Alzheimer's disease provides novel insights into the mechanism of amyloid- \\{beta\\} immunothera. J Neurosci 31: 4124-4136. An example of combination therapy simultaneously affecting $A \beta$ production and clearance pathways in conditional model of $A \beta$ amyloidosis (TetOff-APP mice)

Westerman MA, Cooper-Blacketer D, Mariash A, Kotilinek L, Kawarabayashi T, Younkin LH et al (2002). The relationship between Abeta and memory in the Tg2576 mouse model of Alzheimer's disease. J Neurosci 22: 1858-1867.

Whitehouse PJ, Price DL, Struble RG, Clark AW, Coyle JT, Delon MR (1982). Alzheimer's disease and senile dementia: loss of neurons in the basal forebrain. Science 215: 1237-1239.

Wilcock DM, Alamed J, Gottschall PE, Grimm J, Rosenthal A, Pons J et al (2006). Deglycosylated anti-amyloid-beta antibodies eliminate cognitive deficits and reduce parenchymal amyloid with minimal vascular consequences in aged amyloid precursor protein transgenic mice. J Neurosci 26: 5340-5346. Demonstration that deglycosylation of anti-A $\beta$ antibodies may decrease side effects such as the increased vascular amyloid deposition and microhemorrhage but retains the cognition-enhancing and amyloid-reducing properties of anti-A $\boldsymbol{\beta}$ immunotherapy.

Wilcock DM, Gharkholonarehe N, Van Nostrand WE, Davis J, Vitek MP, Colton CA (2009). Amyloid reduction by amyloid-beta vaccination also reduces mouse tau pathology and protects from neuron loss in two mouse models of Alzheimer's disease. J Neurosci 29: 7957-7965.

Wilcock DM, Rojiani A, Rosenthal A, Subbarao S, Freeman MJ, Gordon MN et al (2004). Passive immunotherapy against Abeta in aged APP-transgenic mice reverses cognitive deficits and depletes parenchymal amyloid deposits in spite of increased vascular amyloid and microhemorrhage. J Neuroinflammation 1: 24 .

Willem M, Garratt AN, Novak B, Citron M, Kaufmann S, Rittger A et al (2006). Control of peripheral nerve myelination by the beta-secretase BACE1. Science 314: 664-666.

Wong HK, Sakurai T, Oyama F, Kaneko K, Wada K, Miyazaki H et al (2005). beta Subunits of voltage-gated sodium channels are novel substrates of beta-site amyloid precursor protein-cleaving enzyme (BACE1) and gamma-secretase. J Biol Chem 280: 23009-23017.

Wong PC, Price DL (2005). Neurobiology of Alzheimer's Disease. In: Brady ST, Siegel GD, Albers RW and Price DL (eds). Basic Neurochemistry. Elsevier. pp. 781-790.

Woodcock J, Griffin JP, Behrman RE (2011). Development of novel combination therapies. N Engl J Med 364: 985-987.

Zhang L, Song L, Terracina G, Liu Y, Pramanik B, Parker E (2001). Biochemical characterization of the gamma-secretase activity that produces beta-amyloid peptides. Biochemistry 40: 5049-5055. 